\title{
WHOSE PRECAUTION AFTER ALL? \\ A COMMENT ON THE COMPARISON AND EVOLUTION OF RISK REGULATORY SYSTEMS
}

\author{
JONATHAN B. WIENER ${ }^{* *}$
}

\section{INTRODUCTION}

A century ago, Oscar Wilde spun the story of the Canterville Ghost, who haunts a stately British manor and terrifies its European denizens, rattling chains at night and leaving bloodstains on the carpet. ${ }^{1}$ But the Otis family arrives from America and buys Canterville Chase, undaunted by the ghost. Scoffs Mr. Otis upon purchasing the manor: "I will take the furniture and the ghost at a valuation. I come

\footnotetext{
Copyright (C) 2003 by Jonathan B. Wiener.

* In the spirit of Herbert L. Bernstein, Whose Advantage After All?: A Comment on the Comparison of Civil Justice Systems, 21 U.C. DAVIS L. REV. 587 (1988).

** Professor of Law, of Environmental Policy, and of Public Policy Studies, Duke University; Faculty Director, Duke Center for Environmental Solutions; University Fellow, Resources for the Future. This work was supported in part by the Duke Center for Environmental Solutions, the German Marshall Fund-U.S., and the Smith Richardson Foundation. I am grateful to Lucas Bergkamp, Francesca Bignami, Mark Cantley, Deborah DeMott, Donald Elliott, Elizabeth Fisher, George Gray, James Hammitt, Donald Horowitz, Bruce Jentleson, Andreas Kraemer, Judith Kelley, Robert Keohane, Helen Ladd, Ragnar Lofstedt, Jonathan Losos, Richard Merrill, Ralf Michaels, Granger Morgan, Madeline Morris, Michael Rogers, Peter Sand, Greg Shaffer, Richard Stewart, Cass Sunstein, David Vogel, Katrina Wyman, and Franklin Zimring for helpful comments; to Salwa Elshazly Amy Horner, Leah Russin and Emily Schilling for excellent research assistance; and to Joan Ashley, Ann McCloskey, and David Menzies for editorial assistance.

Above all I owe thanks to my late colleague Herbert Bernstein, who was an exceedingly kind and generous guide to a young newcomer at Duke. More than that, I saw in him the empathy of a parallel life. As he was growing up in Germany in the 1930s, my mother was growing up in Vienna. Both survived the war (she was smuggled out of Austria at age 8 in 1938, just after the Anschluss) and found a new life in America. I suppose my interest in comparing U.S. and European regulatory systems derives in part from my personal ties to Europe. Certainly my interest in European law was much encouraged by Herbert.

1. Oscar Wilde, The Canterville Ghost, COURT AND SOCIETY REVIEw, Feb. 23, 1887, reprinted in OSCAR WILDE, LORD ARTHUR SAVILE'S CRIME AND OTHER PROSE PIECES (1908), reprinted in 9 THE FIRST COLLECTED EDITION OF THE WORKS OF OSCAR WILDE, 1908-1922, at 65-119 (Robert B. Ross ed. 1969).
} 
from a modern country, where we have everything that money can buy; and with all our spry young fellows painting the Old World red, and carrying off your best actors and prima-donnas, I reckon that if there were such a thing as a ghost in Europe, we'd have it at home in a very short time in one of our public museums, or on the road as a show." The ghost does his best to frighten the Otises, but they nonchalantly barrage the ghost with American technology, commercialism, and fearlessness. ${ }^{3}$ When the ghost rattles at the bedroom door in the middle of the night, Mr. Otis springs up, shoves into the ghost's skeletal hands a bottle of Tammany Rising Sun Lubricator, brightly advises the ghost to use the oil to stop those chains from squeaking, and calmly returns to bed. ${ }^{4}$ Mr. Otis also applies Pinkerton's Champion Stain Remover and Paragon Detergent to remove the bloodstain in the library. ${ }^{5}$ The Otis children turn the tables on the ghost, devilishly chasing it about the house. ${ }^{6}$ Unable to scare the Americans, the European ghost ultimately capitulates and falls on the mercy of the Otis daughter, who guides his guilty soul to a final resting place where his haunting days can end. ${ }^{7}$

How far has comparative law progressed since Wilde's day? Like Wilde's satire, modern comparisons of risk regulation in the United States and Europe are often cast in stereotypes. They depict Europeans as risk-averse, afraid of the unknown (the ghost in the dark), afraid of new technologies (especially American) and of global markets, jumping to adopt precautionary regulations against the most remote and speculative risks. Meanwhile Americans are seen as riskindifferent or even risk-preferring, blustering blithely past risks (real and imagined), confident that new technology (Pinkerton's Champion this or that) and the power of (American) markets will solve every problem and that precaution is a waste of time and a hindrance to progress.

As Herbert Bernstein would have told us, these are stereotypes, fit for an Oscar Wilde comedy, not for serious analyses of comparative law. In this article, I echo Herbert's admonition to those who would paint stark contrasts between American and European legal

\footnotetext{
2. Id. at 66 .

3. See id. at 69-73.

4. Id. at 75 .

5. Id. at 70 .

6. See id.at $80-82$.

7. See id. at 102-114.
} 
systems based only on a few data points. ${ }^{8}$ As Herbert said, what we need more than abstract claims is "hard-nosed comparative work on clearly defined specific institutions or subject-matter areas."

I argue in this article that despite some divisive rhetoric of late, U.S. and European systems of risk regulation are not divergent in the simple way in which they are claimed to be. Part I documents the claim of divergence and greater European precaution. Part II argues that, instead, U.S. and European risk regulatory systems diverge in some ways, converge in others, and display a complex pattern of interaction. Both the United States and Europe have quite active environmental regulatory systems; the United States has hardly ceased regulating. Both the United States and Europe are often highly precautionary-and on several prominent examples, including particulate air pollution, mad cow disease in blood, youth violence, and terrorism, it is the United States that is acting in the more precautionary manner. The United States and Europe do not diverge as much as is claimed on the general use of precaution in regulation, but they often do diverge on the particular question of which risks to worry about and regulate most. This particularized divergence gives rise to visible conflicts. Part III considers the methods and challenges of comparative law and argues that the broader reality in transatlantic risk regulation is a process of "hybridization," in which both systems borrow legal concepts from each other in a complex and continuous mutual evolution. ${ }^{10}$ Part IV offers concluding thoughts.

\section{THE CLAIM OF GREATER EUROPEAN PRECAUTION}

The conventional wisdom today is that European regulatory law has, since roughly the late 1980 s, become "more precautionary" than U.S. regulatory law. The United States and the European Union

8. See Bernstein, supra note *, at 588, 589, 591 (criticizing work drawing stark contrasts between American and European law for relying on "erroneous information" and adopting "completely misguided" stereotypical assumptions that are "grotesque misconceptions").

9. Herbert L. Bernstein, Comparative Law, 40 AM. J. COMP. L. 261 (1992) (reviewing Bernhard Großfeld, The STRENGTH AND WeAKNESS of Comparative LAW (1990)).

10. This article draws on Jonathan B. Wiener \& Michael D. Rogers, Comparing Precaution in the United States and Europe, 5 J. RISK RES. 317 (2002), available at http://www.env. duke.edu/solutions/precaution_project.html\#Publications (analyzing versions of the Precautionary Principle, comparing American and European regulation, and testing hypotheses to explain the observed pattern); and Jonathan B. Wiener, Convergence, Divergence and Complexity in U.S. and European Risk Regulation, in GREEN GIANTS?: ENVIRONMENTAL POLICIES OF THE U.S. AND THE EUROPEAN UNION (Norman Vig \& Michael Faure eds. forthcoming 2003), available at http://www.law.duke.edu:9000/fac/facpub.html (developing a model of hybridization to account for U.S. and European regulatory evolution). 
(EU) have recently clashed over the regulation of a number of health and environmental risks, from genetically modified (GM) foods to climate change to hormones in beef. In each of these three cases, Europe has sought more stringent measures to prevent uncertain risks of future harm, citing the "Precautionary Principle" as its justification $^{11}$; and in each of these cases, the United States has demurred. As to hormones in beef and GM foods, the United States sued the EU in the World Trade Organization (WTO). As to climate change, President Clinton signed the Kyoto Protocol but would not submit it to the U.S. Senate for ratification, and President Bush later withdrew from the Kyoto negotiations entirely.

More generally, observers cite the emphasis placed by U.S. Presidents since Jimmy Carter on cost-benefit analysis of new regulations, the increasing influence of environmental organizations and parties in European regulatory politics, and the growing role of

11. There is no single accepted version of the Precautionary Principle (PP). One author catalogues 19 different interpretations. See Per Sandin, Dimensions of the Precautionary Principle, 5 HuM. \& ECOLOGICAL RISK ASSESSMENT 889 (1999). I speak of precaution as a continuous variable, with policies being "more precautionary" where they act earlier and more stringently to forestall an uncertain future risk. In its most basic narrative form, the PP is a principle that permits precautionary action (regulation) to prevent an uncertain future risk in advance of complete evidence about the risk. For example: "Where there are threats of serious or irreversible damage, lack of full scientific certainty shall not be used as a reason for postponing measures to prevent environmental degradation." Bergen Ministerial Declaration on Sustainable Development in the ECE Region, Article 7, UN Doc. A/CONF.151/PC/10, in 1 Yearbook of International Environmental Law 429 (1990). This version is unobjectionable but not very helpful to decisionmaking. There is never "full scientific certainty"; we always face uncertainty, and we must always make decisions under uncertainty. This version of the PP does not answer the real question: what action to take, given the risks, costs, and inevitable uncertainties. Other versions of the PP are more aggressive, going so far as to forbid the potentially risky activity until the proponent of the activity demonstrates that it passes a specified standard such as no harm, safety, or acceptable risk. For example: "As described in the Wingspread Statement on the Precautionary Principle, the applicant or proponent of an activity or process or chemical needs to demonstrate to the satisfaction of the public and the regulatory community that the environment and public health will be safe. The proof must shift to the party or entity that will benefit from the activity and that is most likely to have the information." Wingspread Statement on the Precautionary Principle, January 25, 1998, reprinted in ProteCTING PUBLIC HeAlth AND THE EnVIRONMENT: IMPLEMENTING THE PRECAUTIONARY PRINCIPLE 353 (Carolyn Raffensperger and Joel Tickner eds. 1999). See also THE PRECAUTIONARY PRINCIPLE AND INTERNATIONAL LAW, 265 (David Freestone \& Ellen Hey eds. 1996) (analyzing the PP as shifting the burden of proof and setting a standard of proof). This version could be excessively stringent, depending on the standard that must be met; a requirement that no activity proceed unless its proponents can show it would cause "no harm" would be tantamount to a ban. Such a standard could not be met by any activity, including medicine, manufacturing, and indeed precautionary regulation itself (which may reduce the target risk but create new countervailing risks). See Jonathan B. Wiener, Precaution in a Multirisk World, in HuMAN AND ECOlOGICAL Risk AsSESSMENT: THEORY AND PRACTICE 1509-1531 (Dennis J. Paustenbach ed. 2002) (hereinafter Wiener, Multirisk World). 
European institutions borne of European integration in the 1990s. ${ }^{12}$ These are clearly important developments; European environmental policy is evolving, and the United States can learn much from the emerging European policy experience.

The Precautionary Principle is frequently advocated to justify and mobilize anticipatory regulation of uncertain risks. ${ }^{13}$ The notion of precautionary regulation is not new; prominent endorsements have appeared in both Europe and the United States since at least the 1970s. The cognate concept of vorsorgeprinzip in German law dates at least to the early 1970s. ${ }^{14}$ In the United States, landmark cases such as Ethyl Corp. v. EPA ${ }^{15}$ and TVA v. Hill ${ }^{16}$ vindicated the notion of precautionary regulation under the Clean Air Act and the Endangered Species Act, respectively; and pre-market safety review of new drugs under the Federal Food, Drug, and Cosmetic Act has an even older pedigree. ${ }^{17}$ U.S. law has frequently adopted precautionary approaches, though no generic principle of precaution. ${ }^{18}$

In recent years the ambition of precaution as an overarching "principle" to govern all risk regulation has grown. It is paid homage in several important international agreements, including several treaties on Marine Pollution, the Rio Declaration, the Framework Con-

12. See Ludwig Kraemer, Development of Environmental Policies in the US and Europe: Convergence or Divergence? in GREEN GIANTS? ENVIRONMENTAL POLICIES OF THE UNITED STATES AND THE EUROPEAN UNION (Norman J. Vig \& Michael G. Faure eds. forthcoming 2003) (arguing that since the early 1980s, European environmental law has become more precautionary because of the increasing integration of E.U. institutions coupled with a commitment to precaution and to the environment as a fundamental value, whereas U.S. environmental law has become less precautionary because of increasing use of cost-benefit analysis, risk assessment, and economic considerations); Theofanis Christoforou, The Precautionary Principle, Risk Assessment, and the Comparative Role of Science in the European Community and the United States Legal Systems, in GREEN GIANTS, supra (arguing that Europe favors the precautionary principle while the U.S. favors risk assessment and cost-benefit analysis). Messrs. Kraemer and Christoforou are senior attorneys at the European Commission.

13. See, e.g., James Cameron \& Juli Abouchar, The Precautionary Principle: A Fundamental Principle of Law and Policy for the Protection of the Global Environment, 14 B.C. INT'L \& COMP. L. REV. 1 (1991).

14. See Sonja Boehmer-Christiansen, The Precautionary Principle in Germany-Enabling Government, in INTERPRETING THE PRECAUTIONARY PRINCIPLE 31, 33 (Tim O'Riordan \& James Cameron eds., 1994) (describing the advance of "vorsorgeprinzip," or the principle of foresight and caution, in Germany in the 1970s).

15. 541 F.2d 1 (D.C. Cir. 1976).

16. 437 U.S. 153 (1978).

17. Federal Food and Drugs Act of June 30, 1906, ch. 3915, § 1, 34 Stat. 768, repealed by Section 902(a) of Act of June 25, 1938, ch. 675, 52 Stat. 1059 (current version at 21 U.S.C. $\$ 301$ ).

18. See John Appelgate, The Precautionary Preference: An American Perspective on the Precautionary Principle, 6 HuM. \& ECOLOGICAL RisK AsSESSMENT 413 (2000). 
vention on Climate Change, the Cartagena Protocol on BioSafety, and the Stockholm Convention on Persistent Organic Pollutants (POPs). ${ }^{19}$ The treaties that constitute the EU expressly provide that EU environmental policy shall be "based on the precautionary principle." ${ }^{20}$ The European Commission has formally articulated and endorsed the Precautionary Principle, ${ }^{21}$ and the European Environment Agency has published a book on the advantages of precaution. ${ }^{22}$ Proponents have forecast that it "could become the fundamental principle of environmental protection policy and law." ${ }^{23}$ Some assert that the Precautionary Principle may already be so widely adopted that it is ripening into an enforceable norm of customary international law, from which no nation can dissent. ${ }^{24}$

The United States, however, has not officially adopted the Precautionary Principle as a general basis for all risk regulation. After initial endorsements of precautionary regulation in the 1970s cases like Ethyl Corp. and TVA v. Hill, in 1980 the U.S. Supreme Court held in the Benzene case ${ }^{25}$ that OSHA cannot regulate on the basis of mere conjecture about uncertain risks; the court ruled that the agency

19. E.g., the Rio Declaration, Article 15; United Nations Conference on Environment and Development: Framework Convention on Climate Change, 31 I.L.M. 849 (1992), art. 3.3. See Nicolas de Sadeleer, Environmental Principles: From Political Slogans to Legal Rules 94-100 (2002); Daniel Bodansky, Scientific Uncertainty and the Precautionary Principle, EnVIRONMENT, Sept. 1991, at 4; Ellen Hey, The Precautionary Concept in Environmental Policy and Law: Institutionalizing Caution, 4 GEO. INT'L ENVTL. L. REV. 303 (1992).

20. Treaty of Amsterdam Amending the Treaty on European Union, the Treaties Establishing THE EUROPEAN COMMUNITIES AND CERTAIN RELATED ACTS, Oct. 2, 1997 O.J. (C 340) art. 174 (formerly Single European Act, Article 130R (1987)), reprinted as EUROPEAN UNION: CONSOLIDATED VERSION OF THE TREATY ON EUROPEAN UNION AND CONSOLIDATED VERsion Of THE TREATy Establishing THE European COMMUNity, 37 I.L.M. 56, 116-117 (1998).

21. Commission of the European Communities, Communication from the Commission on the Precautionary Principle, COM(2000)1, Brussels, Feb. 2, 2000, available at http://europa.eu. $\mathrm{int} / \mathrm{comm} / \mathrm{dgs} /$ health_consumer/library/pub/pub07_en.pdf (hereinafter Communication on the Precautionary Principle).

22. European Environment Agency (EEA), Late Lessons from Early Warnings: The Precautionary Principle 1896-2000, Environmental Issue Report No. 22 (Luxembourg: Office for Official Publications of the European Communities, 2001).

23. Cameron \& Abouchar, supra note 13, at 2 (emphasis in original).

24. See PhilipPe SANDS, Principles of InTERnAtional ENVIRONMENTAL LAW 212-13 (1995) (advocating adoption of the Precautionary Principle as an enforceable norm of customary international law). See also Peter H. Sand, The Precautionary Principle: A European Perspective, 6 HuM. \& ECOLOGICAL RisK ASSESSMENT 445, 448 (2000) (noting that the Supreme Court of India has deemed the Precautionary Principle to be an enforceable norm of customary international law) (hereinafter Sands, Precautionary Principle).

25. Industrial Union Dept., AFL-CIO v. American Petroleum Institute, 448 U.S. 607 (1980) (hereinafter Benzene). 
must demonstrate "significant risk" before regulating. ${ }^{26}$ This decision, and a 1983 guidebook from the National Academy of Sciences, spurred widespread adoption of scientific risk assessment as the basis for American risk regulation over the past two decades, while European regulation has remained more qualitative and informal. ${ }^{27}$ Later, the United States insisted on qualifying the statement of the Precautionary Principle in the Climate Change Treaty, ${ }^{28}$ and the United States responded to the European Commission's recent endorsement of the Precautionary Principle with a long list of skeptical questions. ${ }^{29}$

Today, the conventional wisdom is that Europe endorses the Precautionary Principle and seeks proactively to regulate risks, while the United States opposes the Precautionary Principle and waits more circumspectly for evidence of actual harm before regulating. ${ }^{30}$ In 1999 the Trade Commissioner of the European Union, Pascal Lamy, asserted that "in the U.S. they believe that if no risks have been proven about a product, it should be allowed. In the EU we believe some-

26. Benzene, 448 U.S. at 655 .

27. See Sheila Jasanoff, Risk Management And Political Culture (1986); Sheila JASANOFF, SCIENCE AT THE BAR (1995); Sheila Jasanoff, Contingent Knowledge: Implications for Implementation and Compliance, in ENGAGING COUNTRIES: STRENGTHENING COMPLIANCE WITH INTERNATIONAL ENVIRONMENTAL ACCORDS 63 (Edith Brown Weiss \& Harold K. Jacobson eds. 1998).

28. See United Nations Framework Convention on Climate Change, May 29, 1992, 31 I.L.M. 849 (entered into force March 21, 1994), Article 3.3. The United States initially resisted this provision and then secured addition of the words "cost-effective" as well as accompanying discussion of the "comprehensive approach" and other matters. See Daniel Bodansky, The United Nations Framework Convention on Climate Change: A Commentary, 18 YALE J. INT'L L. 451, 503-504 (1993).

29. U.S. Department of State, Questions from the United States on the Commission's Communication on the Precautionary Principle, March 2000 (copy on file with author) (questioning, inter alia, the terms, scope and enforceability of the precautionary principle under European and international law).

30. See, e.g., Kraemer, supra note 12; Christoforou, supra note 12; Stephan-Gotz Richter, The U.S. Consumer's Friend, N.Y. TIMES, Sept. 21, 2000, at A31 (lauding "the advantages of European intervention in everything from ... antitrust policy to food safety" and charging that "the American government is inclined toward allowing industry to regulate itself"); David L. Levy \& Peter Newell, Oceans Apart? Business Responses to Global Environmental Issues in Europe and the United States, ENVIRONMENT, Nov. 2000, at 9, 10 (describing the "conventional wisdom" that "Europeans demonstrate their considerable concern about environmental issues" while "people in the United States are more individualistic, more concerned about their lifestyles than about the environment, and more ideologically averse to regulation.") (internal citation omitted); Willett Kempton \& Paul P. Craig, European Perspectives on Global Climate Change, ENVIRONMENT, April 1993, at 16-20, 41-45 (arguing that Europeans are more concerned than are Americans about environmental impacts on future generations and on developing countries and more likely to invoke caution regarding unforeseen risks and that Americans are more concerned about the economic costs of regulation and more optimistic about future technological solutions to environmental problems). 
thing should not be authorized if there is a chance of risk." ${ }^{\text {11 }}$ Fifteen years ago, comparisons of U.S. and European regulation found different procedural approaches but similar degrees of regulatory stringency. ${ }^{32}$ Nowadays, mixing the new conventional wisdom with a more nuanced view, leading scholars of comparative regulation describe a "flip-flop:" they argue that the United States was more precautionary than Europe in the 1970s, but Europe has become more precautionary than the United States since the 1990s. ${ }^{33}$ Echoing that view, a senior environmental official of the European Commission said that the United States "was definitely leading European policy back in the 1970s and early 1980s," but now "Europe has certainly managed to catch up" and on some issues "has taken over the role as world leader." ${ }^{4}$ David Vogel writes: "from the 1960s through the mid 1980 s, the regulation of health, safety and environmental risks was generally stricter in the United States than Europe. Since the mid 1980s, the obverse has often been the case." "35 He emphasizes that these trends "have not produced policy convergence. On the contrary, European and American regulatory policies are now as divergent as they were three decades ago. What has changed is the direction of this divergence. In a number of areas, Europe has become more risk-averse, America less so."

Normative evaluations of this situation vary. Some observers see a civilized, safe, careful Europe confronting a risky, reckless, and

31. Steve Charnovitz, The Supervision of Health and Biosafety Regulation by World Trade Rules, 13 TUL. ENVTL. L. J. 271, 295, n.181 (2000).

32. See David Vogel, National Styles of Regulation (1986); Jasanoff, Risk Management And Political Culture, supra note 27; Ronald Brickman, Sheila JASANOFF \& THOMAS Ilgen, , CONTROLling CHEMICALS: THE POLITICS OF REGULATION IN EUROPE AND THE UNITED STATES (1985).

33. See Olivier Cadot \& David Vogel, France, the United States, and the Biotechnology Dispute, Brookings Foreign Policy Studies (Jan. 2001), available at http://www.brookings. edu/fp/cusf/analysis/biotech.htm (last visited March 4, 2003); Diahanna Lynch \& David Vogel, Apples and Oranges: Comparing the Regulation of Genetically Modified Food in Europe and the United States, paper prepared for the American Political Science Association annual meeting, 31 August-3 September 2000; Ragnar E. Lofstedt \& David Vogel, The Changing Character of Regulation: A Comparison of Europe and the United States, 21 RISK ANALYSIS 399, 401 (June 2001) (dubbing this switch the regulatory "flip-flop"); David Vogel, Ships Passing in the Night: The Changing Politics of Risk Regulation in Europe and the United States, Robert Schuman Centre for Advanced Studies, European University Institute, Working Paper 2001/16, 1 (2001) (hereinafter Vogel, Ships Passing).

34. Jorgen Henningsen, The Seven Principles of European Environmental Policies, in Toward a Transatlantic Environmental PoliCy 25-26 (The European Institute, 1992).

35. Vogel, Ships Passing, supra note 33, at 1.

36. Id. at 31. 
violent America. ${ }^{37}$ To this group, the Precautionary Principle is an antidote to industrialization, globalization, and American risk-taking. On the other hand, other observers see a fearful, statist, protectionist Europe trying to rise in the post-Cold War era to challenge a marketbased, scientific, entrepreneurial United States. ${ }^{38}$ To this group, the Precautionary Principle is an obstacle to science, trade and progress. Shades of Oscar Wilde.

\section{THE MORE COMPLEX REALITY}

The claim of greater European precaution is based on a limited examination of a few highly visible examples, such as hormones in beef and genetically modified (GM) foods, plus a set of changes in legal language. But a broader and more detailed analysis of several strata of the American and European regulatory systems reveals a much more complex reality. By dividing the analysis into eight functional component parts of the regulatory process-(A) framing, (B) risk assessment methods, (C) risk management standards, (D) choice of risks to regulate, $(\mathrm{E})$ choice of policy instruments, $(\mathrm{F})$ degree of integration across hazards and media, $(\mathrm{G})$ enforcement mechanisms, and $(\mathrm{H})$ hierarchical level of government-one can better appreciate the multifaceted relations between U.S. and European environmental policies. One can see both convergence and divergence, depending on the component being examined and the degree of magnification or aggregation. Overall, as discussed in Part III below, one sees a complex pattern of hybrid evolution.

\section{A. Framing}

As noted above in Part I, the EU has advocated the "precautionary principle" in international environmental and trade fora, while the United States (under Presidents George W. Bush, Bill Clinton and George H.W. Bush) has consistently expressed reservations. This divergence at the level of high rhetoric or issue framing has led to

37. See Richter, supra note 30; Suzanne Daley, Europe's Dim View of U.S. Is Evolving Into Frank Hostility, N.Y. TIMES, April 9, 2000, at A1 (citing widespread European fear of the U.S. as violent-e.g., guns, death penalty; profit-driven; heartless-lets poor go without medical insurance; and imperialist—forcing its military, culture and products on others); Donald G. McNeil, Jr., Protests on New Genes and Seeds Grow More Passionate in Europe, N.Y. TIMES, March 14, 2000, at A1, A10 (quoting Pierre Lellouche, a member of the French Parliament committee on environmental safety, "The general sense here is that Americans eat garbage food, that they're fat and that they don't know to eat properly.").

38. See John Redwood, Stars And Strife: The Coming Conflicts Between the USA AND THE EUROPEAN UNION (2001). 
frequent claims that Europe has become "more precautionary" than the United States. This divergence in the rhetorical objectives of environmental regulation may reflect real differences in regulatory policy. Or it may reflect conclusions drawn from a few visible cases such as GM foods but not a full characterization of the broad array of regulatory policies. Or it may reflect exaggerated group contrasts and perhaps actual group polarization, ${ }^{39}$ possibly spurred by a new dynamic of international rivalry for policy leadership after the end of the Cold War. ${ }^{40}$ Given that the United States and Europe are both at the highly precautionary end of the global spectrum, and given the findings discussed below of simultaneous actual precaution when viewed across a broader set of risks, the stark claim of divergence between European precaution and U.S. policy seems overdrawn-heuristic, symbolic, or normative rather than descriptively accurate.

\section{B. Risk Assessment}

At least since the U.S. Supreme Court's Benzene decision in 1980, it has been observed that the United States takes a more formal scientific and quantitative approach to risk assessment, while the European approach is more qualitative. ${ }^{41}$ Yet there are signs of convergence. The European Commission espoused scientific risk assessment as a predicate to any invocation of the precautionary principle $^{42}$ and the European Court of Justice held, in a case on mad cow disease (BSE) quite reminiscent of Benzene, that Member State governments may not invoke precaution to regulate risks that the Commission has deemed insignificant. ${ }^{43}$

39. See infra Part IV.A.

40. Ivo H. Daalder, Are the United States and Europe Heading for Divorce?, 77 INT'L AFF. 553-567 (2001); Robert Kagan, Power \& Weakness, POL'Y REV. (June 2002), available at http://www.policyreview.org/JUN02/kagan_print.html (last visited March 4, 2003); ROBERT Kagan, Of Paradise AND Power: America ANd Europe in THE NeW World Order (2003).

41. See supra text accompanying notes 26-29.

42. Commission of the European Communities, Communication on the Precautionary Principle, supra note 21.

43. Case 1/00, Commission of the European Communities v. French Republic (Failure of a Member State to fulfill its obligations - Refusal to end the ban on British beef and veal), 2001 E.C.R. I-09989 (European Court of Justice, 2001). The BSE case could also be analogized to U.S. decisions under the Dormant Commerce Clause, such as City of Philadelphia v. New Jersey, 437 U.S. 617 (1978), because France was maintaining a ban on imports of British beef in violation of the principle of free movement of goods within the Single European Market. But the ECJ's decision recognized that, under the precautionary principle, a member state could maintain higher food safety standards than those set by the European Commission, if the member state had a good reason ( $c f$. Maine v. Taylor, 477 U.S. 131 (1986). The ECJ"s decision 
On the other hand, in September 2002 the European Court of First Instance issued decisions in two cases that seem to cut against the need for a risk assessment prior to adopting a regulation. In Pfizer Animal Health S.A. v. Council of the $E U,{ }^{44}$ the court upheld a ban on using the antibiotic virginiamycin in animal feed because of the potential for such use to generate resistant bacteria that could later infect humans. On the same day, the Court of First Instance decided Alpharma Inc. v. Council of the $E U,{ }^{45}$ upholding a ban on the antibiotic bacitracin zinc in animal feed on similar grounds. The two decisions can be read narrowly as exempting this regulation from the requirement of a risk assessment on the sole ground that the regulation was adopted before the European Commission published its February 2000 Communication on the Precautionary Principle. ${ }^{46}$ If so, then for regulations adopted after February 2000, the criterion of a risk assessment may be binding. But the court in Pfizer also ruled that under the precautionary principle in EC Treaty 174 (formerly 130R), and under Article 11 of Directive 70/524 (which provides that the Community institutions may withdraw authorization of an additive in animal feed where use of the additive constitutes "a danger to ... human health"), an additive could be banned even when no risk assessment had been conducted, when there was limited or no evidence of such bacterial resistance arising, when there was no present need for the use of such antibiotics in human medicine, and when the European Community's Scientific Committee for Animal Nutrition (SCAN) had recommended against a ban. Said the court:

[W] here there is scientific uncertainty as to the existence or extent of risks to human health, the Community institutions may, by reason of the precautionary principle, take protective measures without having to wait until the reality and seriousness of those risks become fully apparent... . Thus, in a situation in which the precautionary principle is applied, which by definition coincides with a

turned on whether France's scientific appraisal of the safety of British beef could overcome the Commission's appraisal. The ECJ held that it could not-that the Commission's scientific findings overruled those of France. This conclusion is somewhat striking in light of the Commission's Communication on the Precautionary Principle, supra note 21, which says that precautionary action may be based on a minority scientific viewpoint.

44. Case T-13/99, Pfizer Animal Health S.A. v. Council, 2002 WL 31337 (European Court of First Instance, Sept. 11, 2002).

45. Case T-70/99, Alpharma Inc. v. Council, 2002 WL 31338 (European Court of First Instance, Sept. 11, 2002).

46. See Pfizer, If 122; Alpharma Inc. v. Council, 143. Both cases also noted that although the precautionary principle in EC Treaty Art. 174 (formerly 130R) is expressly applied to environmental policy, the ECJ has held that it applies to health regulatory policy as well (citing the $B S E$ case, CEC v. French Republic, 2001 E.C.R. I-09989). 
situation in which there is scientific uncertainty, a risk assessment cannot be required to provide the Community institutions with conclusive scientific evidence of the reality of the risk and the seriousness of the potential adverse effects were that risk to become a reality.... [But] a preventive measure cannot properly be based on a purely hypothetical approach to the risk, founded on mere conjecture which has not been scientifically verified ... Rather, it follows from the Community Courts' interpretation of the precautionary principle that a preventive measure may be taken only if the risk, although the reality and extent thereof have not been 'fully demonstrated by conclusive scientific evidence,' appears nevertheless to be adequately backed up by the scientific data available at the time when the measure was taken. ${ }^{47}$

These statements are confusing. To be sure, precaution must involve action under uncertainty. But since all decisions involve "situations in which there is scientific uncertainty," the court seems to be saying that a risk assessment is never required. The court also seems to misunderstand what a risk assessment would do, presuming that it would provide "conclusive scientific evidence," which of course is never available. Then the court holds that without such "conclusive scientific evidence," the finding of risk must be "adequately backed up" by the "available" scientific data. This new standard, if it can be called that, is highly ambiguous and may generate additional litigation over the colloquial terms "adequately," "backed up" and "available," and perhaps the question of whether preliminary indications of risk qualify as "scientific data."

Later the court tied the power to adopt precautionary measures to the regulatory body's determination of the level of acceptable risk and the tradeoff between gathering additional information to improve the policy and delay. It observed:

$[\mathrm{U}]$ nless the precautionary principle is to be rendered nugatory, the fact that it is impossible to carry out a full scientific risk assessment does not prevent the competent public authority from taking preventive measures, at very short notice if necessary, when such measures appear essential given the level of risk to human health which the authority has deemed unacceptable for society.

... In such a situation, the competent public authority must therefore weigh up its obligations and decide either to wait until the results of more detailed scientific research become available or to act on the basis of the scientific information available. Where measures for the protection of human health are concerned, the outcome of that balancing exercise will depend, account being taken of the particular circumstances of each individual case, on the level of

47. Pfizer, IIII. 139, 142-44 (emphases added). 
risk which the authority deems unacceptable for society. ${ }^{48}$

The court seems likely to defer to the regulatory body's choice of the level of acceptable risk and to its evaluation of this tradeoff between information and delay. ${ }^{49}$ The court also held that the recommendations of SCAN are purely advisory and may be rejected by the Commission and the Council. ${ }^{50}$ Near the end of its opinion, the court mentioned that such precautionary regulations adopted before "full" scientific evidence is available are to be "provisional ... pending the availability of additional scientific evidence." $"$ But it remains unclear whose burden it will be to gather such additional information and when the regulatory body could be required to revise the regulation in light of the new science.

The court in Alpharma added that a ban could be upheld without a risk assessment even when the Council and Commission had not even asked the SCAN for an opinion. ${ }^{52}$ The court reiterated that when Community institutions act under the precautionary principle, judicial review is to be very deferential. ${ }^{53}$

These decisions appear unlikely to be appealed to the ECJ,

\footnotetext{
48. Id. IIT. $160-61$.
}

49. See id., III. 169-70 ("It follows that in this case, in which the Community institutions were required to undertake a scientific risk assessment and to evaluate highly complex scientific and technical facts, judicial review of the way in which they did so must be limited. The Community judicature is not entitled to substitute its assessment of the facts for that of the Community institutions, on which the Treaty confers sole responsibility for that duty. Instead, it must confine itself to ascertaining whether the exercise by the institutions of their discretion in that regard is vitiated by a manifest error or a misuse of powers or whether the institutions clearly exceeded the bounds of their discretion..... In particular, under the precautionary principle the Community institutions are entitled, in the interests of human health to adopt, on the basis of as yet incomplete scientific knowledge, protective measures which may seriously harm legally protected positions, and they enjoy a broad discretion in that regard.”). Accord, id., If 323.

50. Pfizer, III 196, 200-201, 204. The court said that the regulatory bodies may reject the advice of SCAN so long as they give reasons for doing so, which may include that the action is "in the interest of human health protection," $i d$. II 205. This appears to empower the Commission and the Council to regulate wherever they assert the requisite interest, regardless of the evidence of risk.

51. Pfizer, II 387.

52. See Alpharma, III 152-76, 206 (consulting SCAN is discretionary); II 213 (regulating without consulting SCAN is only permissible in "exceptional circumstances and where there are adequate guarantees of scientific objectivity"); II 240 (in the absence of a SCAN opinion, the Commission and Council may themselves assess the risks "on the basis of information contained in the SCAN opinions relating to the other antibiotics whose authorisation was withdrawn by the contested regulation and in the reports of the various international, Community and national bodies."); III 314-318 (permissible to regulate without consulting SCAN where action is based on previous SCAN reviews of evidence regarding other antibiotics and on evidence from international bodies).

53. See Alpharma, IIII $181,349$. 
whose decision in the $B S E$ case suggests it would reverse. But if they were appealed and upheld by the ECJ, the antibiotics cases would signal that European law will require less in the way of quantitative risk assessment than U.S. law generally has since Benzene. The antibiotics cases are reminiscent of Ethyl Corp. v. EPA $A^{54}$ and Public Citizen Health Research Group v. Tyson. ${ }^{55}$ Short of reversing, the ECJ could limit the applicability of the antibiotics cases. The degree of evidence required before regulating could depend, in European as in American law, on the specific wording of the statute or directive that provides the legal basis for the regulation. Thus, the ECJ could limit the antibiotics cases to the broad "danger" language of Directive 70/524, requiring more risk assessment information under other directives. And the ECJ could limit the antibiotics cases to regulations adopted before the Commission's February 2000 Communication setting forth criteria for invocation of the precautionary principle, including the requirement of a risk assessment. Further, the ECJ could give more emphasis to the ostensibly "provisional" character of precautionary measures, holding that regulations may be adopted without a "full" risk assessment, but that such regulations must be revisited and revised in light of new information within a reasonably prompt period of time. Whether that new information must be generated by the regulatory body or the regulated entity could depend on who is the least-cost provider of the information.

\section{Risk Management: Standard-Setting}

When actual regulatory policy decisions are made, the trend is toward convergence. Both the United States and the European Commission have now adopted risk assessment and benefit-cost analysis as basic criteria for new regulations, ${ }^{56}$ and European law applies the principle of proportionality, which implies balancing benefits and costs. ${ }^{57}$ To be sure, these criteria are not universally applied: for

54. 541 F.2d 1 (D.C. Cir. 1976) (authorizing precautionary regulation and limiting judicial review of agency decisions based on uncertain future risks).

55. 796 F.2d 1479 (1986) (upholding regulation of ethylene oxide despite flaws in risk assessment).

56. Executive Order 12866, Regulatory Review, 58 Federal Register 51735 (September 30, 1993); Commission of the European Communities, Communication on the Precautionary Principle, supra note 21.

57. See Nicholas Emiliou, The Principle of Proportionality in European Law: A COMPARATIVE STUdY (1996); Pfizer, IIII 410-411 ("The Court considers that a cost/benefit analysis is a particular expression of the principle of proportionality in cases involving risk management. ... the principle of proportionality, which is one of the general principles of Commu- 
example, some areas of U.S. environmental law are statutorily exempt from considerations of cost; and the European Commission has invested far less in the institutional capacity needed to review regulations on cost-benefit criteria than has the U.S. executive branch. But the trend is toward convergence. The Bush administration has retained and applied the Clinton administration's Executive Order 12866 on benefit-cost analysis of new regulations, suggesting continuity rather than an abrupt change in policy. European member states have consistently moderated the stringency of the precautionary principle when incorporating it into national law, such as by qualifying it with economic considerations that approach benefit-cost analysis. ${ }^{58}$ And the European Commission has issued a new Action Plan on Improving Regulation which calls for greater application of the proportionality principle and of consolidated impact assessments of new regulations and legislation (including impact assessments of amendments made by the European Parliament and Council to the Commission's legislative proposals). ${ }^{59}$ Coupled with this Action Plan for Improving Regulation is a new guidance on Impact Assessment of all major regulatory actions (including regulation, legislation, and international treaty negotiations), which requires identification of goals, policy alternatives, positive and negative impacts (including tradeoffs; economic, social, and environmental consequences; and impacts on risks), attention to proportionality, and justification for the policy chosen, with the depth of analysis to be proportionate to the significance of the impacts. ${ }^{60}$ Although they are likely to be less quantita-

nity law, requires that measures adopted by Community institutions should not exceed the limits of what is appropriate and necessary in order to attain the legitimate objectives pursued by the legislation in question, and where there is a choice between several appropriate measures, recourse must be had to the least onerous, and the disadvantages caused must not be disproportionate to the aims pursued ..."). But cf. id. If 456 ("The Court observes that the importance of the objective pursued by the contested regulation, i.e. the protection of human health, may justify adverse consequences, and even substantial adverse consequences, for certain traders... The protection of public health, which the contested regulation is intended to guarantee, must take precedence over economic considerations.").

58. See Peter Sand, The Precautionary Principle: A European Perspective, supra note 24; Wiener, Multirisk World, supra note 11.

59. See Commission of the European Communities, Communication from the Commission: Action Plan "Simplifying and Improving the Regulatory Environment," June 5, 2002,

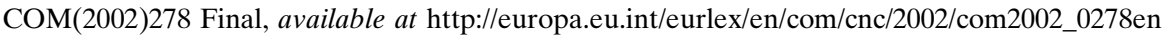
01.pdf .

60. See Commission of the European Communities, Communication from the Commission on Impact Assessment, June 5, 2002, COM(2002)276 Final, available at http://europa.eu.int/ comm/governance/suivi_lb_en.htm. This Impact Assessment guidance, and the Action Plan on Improving Regulation, supra note 59, are both part of a larger set of initiatives on European Governance, described at http://europa.eu.int/comm/governance/suivi_lb_en.htm. It remains to 
tively exacting than is benefit-cost regulatory review in the U.S., the new European approaches to Improving Regulation and Impact Assessment embody the core principles of benefit-cost regulatory review and in some ways go farther than the U.S. approach (such as by covering legislation and international treaty negotiations) and in some ways improve on the U.S. approach (such as by aligning the depth of analysis with its value for affecting policy, rather than the U.S. approach of setting levels of analysis for regulations having arbitrary threshold monetary costs of $\$ 100$ million or $\$ 1$ billion). These developments portend even greater similarity in the use of benefit-cost analysis in the U.S. and European regulatory systems. Both systems also now involve substantial public participation in standard-setting. ${ }^{61}$ David Vogel, who has described the transatlantic posture as a reversal of divergent approaches, ${ }^{62}$ has more recently written of convergence in U.S. and European regulatory approaches. ${ }^{63}$ Similarly, Robert A. Kagan argues that broadly speaking, the substantive environmental standards in the U.S. and Europe are convergent. ${ }^{64}$

Thus the rhetoric of accelerating precaution in Europe and retrenchment in the United States does not capture the broad underlying reality of convergence in the actual basis for standard-setting. Sometimes the cost-benefit shoe is even on the other foot. For example, one recent study finds that the U.S. legal regime for air pollution control is more strict and precautionary than the German regime, in part because U.S. law requires standards to be set without considering cost, whereas the German approach applies consideration of benefits and costs under the principle of proportionality. ${ }^{65}$ Another study finds that European regulation is less susceptible to the problems of tunnel vision (excessive regulation of minor risks) and random agenda selection that have plagued U.S. regulation. ${ }^{66}$ Moreover, it is

be seen how these requirements for regulatory analysis will be implemented and overseen. The European Commission does not yet have an institutional counterpart to the U.S. apparatus of regulatory review by the Office of Management and Budget (OMB).

61. David Vogel, Risk Regulation in Europe and the United States, in YEARBOOK OF EUROPEAN ENVIRONMENTAL LAW, VOL. III (2002), also available at http://faculty.haas. berkeley.edu/vogel/ (last visited Mar. 4, 2003) (hereinafter Vogel, Risk Regulation).

62. Vogel, Ships Passing, supra note 33.

63. Vogel, Risk Regulation, supra note 61.

64. Regulatory EnCOUNTERs 2-3, 376-77 (Robert A. Kagan \& Lee Axelrad eds. 2000).

65. John P. Dwyer, Richard W. Brooks \& Alan C. Marco, The Air Pollution Permit Process for US and German Automobile Assembly Plants, in Kagan \& Axelrad, supra, note 64 at 173, 206-08.

66. Stephen Breyer \& Vreele Heyvaert, Institutions for Regulating Risk, in Environmental Law, The Economy and Sustainable Development: The United 
not the case that cost-benefit analysis necessitates weaker regulation; several examples of greater U.S. precaution, including both the phaseout of chloroflourocarbins and of lead in gasoline in the 1980s, were substantially motivated by cost-benefit analyses. Recently the United States Office of Management and Budget (OMB) has initiated a series of "prompt letters" that use cost-benefit analysis to identify and recommend promising new regulations that the agencies ought to consider adopting but have not yet-using economics to spur smart regulation, not just to block bad regulation. Meanwhile, more precautionary regulation is not always a triumph over industry influence, nor is economic analysis always a capitulation to industry; sometimes industry seeks greater regulation for parochial gain, such as to impose costs on its trade rivals. ${ }^{68}$

And, were the contention true that the use of cost-benefit analysis led to moderating some regulations or strengthening others, whether in the United States or in Europe, that would not necessarily be unwise-indeed it might be quite sensible. That is why the European Commission's "Communication" itself requires cost-benefit analysis as a predicate to precaution. More precautionary policies are not always superior to policies chosen by cost-benefit balancing. Precaution may avoid the harms of inaction on false negatives (risks thought to be minor that turn out to be serious) but incur the harms of overreaction to false positives (risks thought to be serious that turn out to be minor). ${ }^{69}$ Both types of errors are harmful to society. The harms of ignoring false negatives include the health and environmental damages from the unrestricted risk. The harms of regulating false positives include high costs to consumers and workers, unemployment, lost innovations of helpful new products, restrictions on

States, the EURopeAn Union AND the InTERNATIONAL COMMUNity 308-09 (Richard L. Revesz, Philippe Sands \& Richard B. Stewart eds. 2000).

67. See the OMB/OIRA website, http://www.whitehouse.gov/omb/inforeg/prompt_letter. html (last visited June 10, 2003).

68. See Ann P. Bartel and Lacy G. Thomas, Predation through Regulation: the Wage and Productivity Impacts of OSHA and EPA, 30 J.L. \& ECON. 239-64 (1987); Jonathan B. Wiener, On the Political Economy of Global Environmental Regulation, 87 GEORGETOWN L.J. 749-794 (1999).

69. See Richard B. Stewart, Environmental Regulatory Decisionmaking Under Uncertainty, 20 RES. IN LAW \& ECON. 71-152 (2002) (translating the precautionary principle into terms of decision analysis); John D. Graham, Decision-Analytic Refinements of the Precautionary Principle, 4 J. Risk RESEARCH 127 (2001); Ralph L. Keeney \& Detlof von Winterfeldt, Appraising the Precautionary Principle - A Decision Analysis Perspective, 4 J. RISK RESEARCH 191 (2001); Michael Dekay et al., Risk-Based Decision Analysis in Support of Precautionary Policies, 5 J. RISK RESEARCH 391 (2002). 
personal choices, and public cynicism about exaggerated risks ("crying wolf"). An extreme policy of zero risk would bring valuable activities to a halt; applied broadly it would be impossible. The goal is not zero false negatives but the best balance of the two types of errors that we can achieve.

Even ignoring costs, more precautionary policies are not always desirable. In addition to the costs and other inhibitions to innovation that they may engender, more precautionary policies can also increase rather than decrease risk. Precaution against a target risk can induce increases in other countervailing risks. ${ }^{70}$ For example, airbags in cars may save adults but kill children. Banning asbestos may reduce cancers but increase highway fatalities due to less effective brake linings. Reducing ozone in smog may protect our lungs but put our skin at risk from increased ultraviolet radiation. The U.S. FDA's precautionary measures to safeguard the blood supply against mad cow disease may reduce the availability of blood in hospital emergency rooms. Forestalling climate change by shifting to fuel-efficient diesel engines may increase local particulate matter air pollution. Banning one pesticide (e.g., to protect food consumers from residues) may invite the use of a substitute pesticide (e.g., one that leaves less residue but that is more toxic to uninformed migrant workers). Banning all use of DDT (as opposed to banning just its use in agriculture) may increase the spread of malaria, killing millions. Banning chlorination of drinking water may foster deadly outbreaks of cholera and other microbial pathogens. The war on drugs may increase inner city violence. Police chases of fleeing suspects may kill bystanders. Suppressing forest fires may worsen these fires when they occur. In short, such "risk-risk tradeoffs" are ubiquitous. And U.S. or European precautionary policies may act as trade barriers to exports from poorer countries, thereby significantly burdening the have-nots to satisfy the demands of wealthy countries for ever greater precaution against minute risks. For example, bans on genetically modified foods may perpetuate hunger and malnutrition in poor countries. This very dilemma faces Zambia and other famine-stricken African nations, which reject U.S. offers of donated corn, apparently motivated in part

70. John D. GRAHAM \& JONATHAN BAERT WIENER, Risk vs. Risk: TRADEOFFS IN Protecting HeAlTH AND THE ENVIRONMENT (1995); Jonathan Baert Wiener, Managing the Iatrogenic Risks of Risk Management, 9 RISK: ENVIRONMENT HEALTH \& SAFETY 39 (1998). Of course, regulations may also yield unintended ancillary benefits, which should also be counted in a full portfolio analysis. See Graham \& Wiener, supra, at 2, 232, 254; Samuel J. Rascoff \& Richard L. Revesz, The Biases of Risk Tradeoff Analysis: Towards Parity in Environmental and Health-and-Safety Regulation, 69 U. CHI. L. REV. 1763 (2002). 
by the fear that U. S. corn might cross-pollinate Zambian corn, rendering future Zambian corn in violation of European restrictions on imports of genetically modified crops. Therefore the ideal policy stance-even from a purely health and environmental perspective-is not maximum precaution but an optimal precaution that takes into account the tradeoffs among multiple risks.

\section{Choice of Risks}

Disaggregating the overall convergence in regulatory criteria, one can see differences in the degree of precaution regarding particular risks, but no simple divergence in which Europe or the United States is more precautionary than the other across the board. The picture is more complex; relative precaution appears to depend on the risk and the consequences of specific policies than it does on broad national or temporal postures.

1. Overview. Europe appears to be more precautionary than the United States about such risks as:

- genetically modified (GM) foods $^{72}$

- hormones in beef ${ }^{73}$

- toxic chemicals ${ }^{74}$

- phthalates in toys $^{75}$

71. See Wiener, Multirisk World, supra note 11.

72. See Cadot \& Vogel, supra note 33; Lynch \& Vogel, supra note 33; Thomas Bernauer \& Erika Meins, Technological Revolution Meets Policy and the Market: Explaining Cross-National Differences in Agricultural Biotechnology Regulation, EUROPEAN JOURNAL OF POLITICAL RESEARCH (forthcoming 2003).

73. See Wiener \& Rogers, supra note 10, at 323-27; Charnovitz, supra note 31.

74. On June 11, 2003, the European Commission launched a new "European Strategy on Environment and Health," focused on protecting children and other vulnerable groups against the health risks of chemicals, especially simultaneous exposures to multiple chemicals, through a comprehensive approach that avoids cross-media shifts of pollutants . See Communication from the Commission, A European Environment and Health Strategy, COM(2003)338 final, June 11, 2003, as well as additional materials at http://europa.eu.int/comm/press_room/ presspacks/health/pp_health_en.htm (last visited June 16, 2003). The Commission is now also preparing new legislation to implement its February 2001 "White Paper on the Strategy for a Future Chemicals Policy," with public comments on the draft legislation invited until July 10, 2003. See Commission of the European Communities, Directorates General for Enterprise and Environment, Internet Consultation on Draft Chemicals Legislation, available at http://europa.eu.int/comm/environment/chemicals/white paper.htm (last visited June 10, 2003). The new chemicals policy would require testing of existing chemicals in addition to new chemicals. And Sweden has adopted the goal of a "toxins-free society" by 2020 . See Ragnar E. Lofstedt, Swedish Chemical Regulation: An Overview and Analysis, 23 RISK ANALYSIS 411 (2003).

75. The European Commission banned phthalates in young children's teething toys in 1999, citing the precautionary principle, see Karen Bowerman, Europe to Ban PVC Toys, BBC 
- climate change (including cuts in greenhouse gas emissions under the Kyoto Protocol, and the use of diesel fuel to reduce automobile $\mathrm{CO}_{2}$ emissions) ${ }^{76}$

- marine pollution ${ }^{77}$

- guns (gun ownership is far more widespread in America than in Europe $)^{78}$

- teenage consumption of marijuana and other illegal drugs ${ }^{79}$ and

- antitrust/competition policy. ${ }^{80}$

By contrast, the United States appears to be more precautionary than Europe about such risks as:

- new drug approval (e.g., thalidomide, which was licensed in Europe but not in the United States, and more generally, the

News, November 10, 1999, available at http://news.bbc.co.uk/1/hi/health/514242.stm (visited June 10, 2003). The U.S. CPSC has so far found the risk to be very low and has not banned these substances, and on February 22, 2003, the CPSC denied a petition to ban PVC in children's toys. (Phthalates, such as DEHP and DINP, are plasticizers that make hard plastics flexible; they have been used in various products including vinyl, medical equipment, and some baby toys.) See Report to the U.S. CONSUMER Product SAFETy COMmission by the Chronic HAZARD ADVISORY PANEl ON DiISONONYL PHTHALATE (DINP), June 2001, available at (visited June 10, 2003); U.S. Consumer Product Safety Commission, The Risk of Chronic Toxicity Associated with Exposure to Diisononyl Phthalate (DINP) in Children's Products, Dec. 1998, available at http:// www.cpsc.gov/phth/dinp.html (visited June 10, 2003). Studies continue on the effect of phthalates on young children. See Keith Mulvihill, Pediatricians Call for More Action on Phthalates, REUTERS HEALTH, June 4, 2003, available at http://www .ourstolenfuture.org/Commentary/News/2003/2003-0604-RH-pedphthalates.htm (visited June 10, 2003), citing Katherine M. Shea et al., 111 Pediatrics 1467-1472 (June 2003). And the European Commission is now studying the risks of the substitutes for phthalates in childrens toys. See The Availability of Substitutes for Soft PVC CONTAINING Phthalates IN CERTAIN TOYS AND CHILDCARE ARTICLES, Final Report Prepared for the European Commission Directorate-General Enterprise, July 2000, available at http://europa.eu.int/ comm/enterprise/chemicals/legislation/markrestr/studies/phthalates.pdf (last visited June 10, 2003).

76. See Jonathan B. Wiener, On the Political Economy of Global Environmental Regulation, 87 GEO. L.J. 749 (1999); RICHARD B. STEWART \& JONATHAN B. WiENER, Reconstructing Climate Policy (2003); Diesel Technology Forum, Demand for Diesels: The European Experience (July 2001), available at http://faculty.haas.berkeley.edu/vogel/ (last visited Mar. 4, 2003).

77. See DE SAADELEER, supra note 19, at 94-96.

78. See United Nations, International Study on Firearm Regulation 52-53 (1998); and see discussion below in Part III.D.2.

79. See Bjorn Hibell, et al., The 1999 ESPAD Report: Alcohol and Other Drug Use Among Students in 30 European Countries, Council of Europe, Stockholm (2001) (summary available at http://monitoringthefuture.org/pubs/espad_pr.pdf (visited June 10, 2003)).

80. See Richter, supra note 30; Anita Raghavan \& Brandon Mitchener, EU's Antitrust Czar Isn't Afraid to Say No; Just Ask Time Warner, WALL ST. J., Oct. 2, 2000, at A1 (reporting that European competition regulators have become more proactive than U.S. regulators, such that mergers that have U.S. approval get blocked in Europe; "“You wonder sometimes if you're guilty until proven innocent,' says one executive."). 
more cautious pace of new drug approval in the United States. $)^{81}$

- lead in gasoline (petrol) (phased out approximately a decade earlier in the United States than in Europe $)^{82}$

- the stratospheric ozone layer (the United States stopped developing the supersonic transport (SST) in the 1970s on this concern, while Europe pressed ahead with the Concorde; and the United States banned CFCs in aerosol spray cans in 1978, almost a decade before Europe began to phase out $\mathrm{CFCs})^{83}$

- particulate matter (the United States sets more stringent standards for automobile particulate emissions, thereby effectively restricting diesel engines to less than $1 \%$ of the market, compared to over $20 \%$ of the market in Europe where diesel is promoted to reduce $\mathrm{CO}_{2}$ emissions) ${ }^{84}$

- nuclear energy (the United States has regulated civilian nuclear power plants more tightly and has used nuclear energy less than have France and other European countries; and the United States stopped adding to its nuclear power plants after 1980 while Europe and Japan continued to add some re-

81. See Peter Barton Hutt \& Richard A. Merrill, Food and Drug Law, 580-83 (2d ed. 1991); GAO, FDA Drug Approval: A Lengthy Process that Delays the AVAILABILITY OF IMPORTANT NEW DRUGS (1980).

82. The United States phased out lead in gasoline from 1.1 grams per gallon in 1981 to 0.1 grams per gallon by 1987. See 50 Fed. Reg. 9386 (Mar, 7, 1985). By that date the United Kingdom still allowed 0.13 grams of lead per litre, see United Kingdom Dep't of the Environment, Unleaded Petrol: The United Kingdom Position (Feb. 1991), which was about five times greater than the U.S. 0.1 grams per gallon. Many other European countries allowed even more. Lead in gasoline was completely phased in the United States out by 1989. WINSTON HARRINGTON \& VIRGINIA MCCONNELL, MOTOR VEHICLES AND THE ENVIRONMENT 43 (2003), available at http://www.rff.org/reports/PDF_files/CarsEnvironment.pdf (last visited June 10, 2003). At the Aarhus Conference on Environment for Europe in 1998, European countries agreed to phase out lead in petrol completely by 2005. See Environment for Europe, Lead to Be Phased out of Petrol in Europe, June 24, 1998, available at http://www.mim.dk/aarhus conference/press/june/240698a.htm (visited June 10, 2003); United Nations Economic Commission for Europe, Phase-Out of Leaded Petrol, available at http://www.unece.org/env/ europe/phaseout_of_leaded_petrol.htm (visited June 10, 2003) (linking to official "PanEuropean Strategy To Phase Out Leaded Petrol").

83. See KAREN T. Litfin, OzONE Discourses 64-67 (1994) (reporting that Oregon and New York banned CFCs in aerosol spray cans in the mid-1970s; the United States adopted a national ban in 1978 (expressly on the view of the chair of CEQ that "chemicals are not innocent until proven guilty"); but "only Canada, Sweden and Norway ... followed the US lead in implementing an aerosol ban.... Despite pressure from the USA, the ... EC refused to adopt an aerosol ban."). The Montreal Protocol phasing out CFCs was adopted in 1987. Id.

84. See Diesel Technology Forum, supra note 76; HARRINGTON \& MCCONNELL, supra note 82 , at 44 . 
actors $)^{85}$

- teenage consumption of alcohol and tobacco ${ }^{86}$

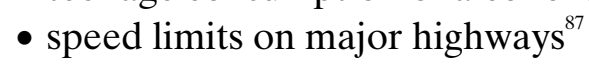

- mad cow disease (BSE) in beef and especially in blood donations $^{88}$

- choking hazards embedded in food ${ }^{89}$

- "right to know" disclosure requirements (the United States has a suite of provisions such as FOIA, NEPA, TRI, CAA 112(r), Calif. Prop 65, OSHA Hazard Communication Standard, while Europe has only recently begun to act in this area $)^{90}$

85. The United States obtains about $18 \%$ of its electricity from nuclear power, while France obtains $79 \%$, Belgium $60 \%$, Sweden $42 \%$, and Germany $29 \%$. See International Atomic Energy Agency, The Energy Challenge: The Nuclear Power Potential (1996), available at http://www. iaea.or.at/worldatom/Press/Booklets/Development/devfive.html (last visited June 10, 2003). On nuclear energy construction since 1980, see Christopher Flavin \& Nicholas Lenssen, Nuclear Power Nears Peak, Worldwatch Institute News Brief, March 5, 1999, available at http://www.worldwatch.org/alerts/990304.html (last visited June 10, 2003) ("In the aftermath of the 1979 Three Mile Island accident, the U.S. nuclear market was the first to deteriorate. No new nuclear plants have been ordered since then, and nuclear generating capacity is now lower than it was a decade ago. Not only have U.S. power companies stopped building nuclear power plants, they have closed six reactors since 1996 that had become too expensive to operate. Meanwhile, seven of Canada's 21 reactors have been "laid up" due to safety concerns and are unlikely to operate again....Western Europe stayed with its nuclear expansion plans longer than the U.S. did, . . . since the 1986 explosion at Chernobyl . . . construction has started on only three new reactors. France, long known as the most pro-nuclear country, now has a moratorium on nuclear plant construction .... In Germany, the discussion is not over whether to build more nuclear plants, but on how quickly to shut down the existing reactors. ... Asia remains the last stronghold for the nuclear power industry, with 88 reactors operating and 26 under construction, though even there, a slowdown is evident. Japan, which obtains 35 percent of its electricity from the atom, only has two reactors under construction, with work starting on one of them in 1998.")

86. See Hibell, et al., supra note 79. Interestingly, the new Framework Convention on Tobacco Control, sponsored by the World Health Organization and adopted on May 21, 2003, see http://tobacco.who.int/, was opposed in part and temporarily by both the United States and Germany - an odd coalition against precaution.

87. See http://www.ibiblio.org/rdu/sl-inter.html (last visited June 10, 2003) (reporting that as of 1992, compared to the U.S. speed limit of 55 (or occasionally 65 or 70) mph, the speed limits in Europe included United Kindom: $70 \mathrm{mph}$; Belgium, Luxembourg, Netherlands, Portugal, and Spain: $75 \mathrm{mph}$; Austria, France and Italy: $81 \mathrm{mph}$; and Germany: Unlimited).

88. See Wiener \& Rogers, supra note 10.

89. See Bryan Harris, A Comparison of U.S. and E.U. Product Safety Regulations: A Case Study, 8 RisK: HEALTH SAFETY \& ENVIRONMENT 209 (1997).

90. The acronyms refer to the Freedom of Information Act, 5 U.S.C. $\S 552$ et seq.; the National Environmental Policy Act (which requires Environmental Impact Statements), 43 U.S.C. $\S 4321$ et seq. (1969); the Toxics Release Inventory, www.epa.gov/tri/, created by 42 U.S.C. $\S$ 11001 et seq. (1986); the Clean Air Act section 112( R) on risk management plans, 42 U.S.C. $\S$ 7412 (r) (1990); California's Proposition 65 requiring carcinogen warnings, Cal. Health \& Safety Code $\$ 25249.5$ et seq. (1986); and the Occupational Safety and Health Administration's Hazard 
- potentially violent persons ${ }^{91}$ such as violent youths, mental health patients, and recovering sex offenders and

- terrorism and weapons of mass destruction (WMD). ${ }^{92}$

The length of these lists is not important; as discussed below in Part IV.A, neither set of examples is yet a representative sample of the full population of cases and thus neither set fully proves a general characterization. Moreover, the point is not a contest to determine who is "more precautionary than thou." This broader set of examples merely indicates that neither the United States nor the EU can claim to be the more precautionary actor across the board, whether today or in the past. Simple contrasts, such as that Americans are risktakers while Europeans are risk-averse, ${ }^{93}$ or that Americans are individualistic and anti-regulation while Europeans are collectivist and pro-regulation, ${ }^{94}$ are unsupported by the evidence of actual regulatory policies. These stereotypes are also at odds with the "flip-flop" hypothesis of greater U.S. precaution followed by greater European precaution.

A better synthesis is that both the United States and Europe are precautionary, but against different risks. Some of these examples are consistent with the "flip-flop" hypothesis: the greater U.S. precaution in the 1970s regarding new drug approval, CFCs in aerosol spray cans, supersonic transport, and the phaseout of lead in gasoline (petrol); and the greater European precaution more recently regarding GM foods, climate, hormones in beef, toxic chemicals, and phthalates. But other examples are inconsistent with the "flip-flop" hypothesis: the greater European precaution in the 1970s regarding marine pollution and guns; and the greater U.S. precaution in recent

Communication Standard, see www.osha.gov/SLTC/hazardcommunications and 29 C.F.R. 1910.1200. See Peter H. Sand, The Precautionary Principle: A European Perspective, 6 HUMAN AND ECOlOGICAL RISK AsSESSMENT 445, 452 (2000), supra note 24; Peter H. Sand, The Reality of Precaution: Information Disclosure by Government and Industry, paper presented at the Second Transatlantic Dialogue on "The Reality of Precaution: Comparing Approaches to Risk and Regulation," Airlie House, 15 June 2002, available at http://www.env.duke.edu/ solutions/documents/sand_airlie_june_2002.doc (last visited Feb. 24, 2003) (hereinafter Sand, Information Disclosure); SUSAN ROSE-ACKERMAN, CONTROLling ENVIRONMENTAL POLICY: THE Limits OF PUBlic LAW IN GERMANY AND THE UNITED STATES (1995).

91. See discussion infra in Part III.D.2.

92. Id.

93. See Wilde, supra note 1; Lamy, quoted in Charnovitz, supra note 31 at 295 n.181.

94. See, e.g., Levy \& Newell, supra note 30 (reporting the "conventional wisdom" that "Europeans demonstrate their considerable concern about environmental issues" while "people in the United States are more individualistic, more concerned about their lifestyles than about the environment, and more ideologically averse to regulation.") (citation omitted). 
years regarding BSE in blood, particulate matter and diesel, smoking, right to know measures, restraints on potentially violent persons, and terrorism. This complexity is compounded by the variation within each system: both are federations of subsidiary jurisdictions, with considerable variety in regulatory approaches across member states. ${ }^{95}$

2. Specific Cases. Analyzing specific examples of recent precautionary policies in more detail helps demonstrate that the pattern is not of increasing European precaution and declining U.S. precaution, but rather simultaneous precaution against different risks. The next four subsections focus on such cases: diesel emissions, mad cow disease, violence, and terrorism.

a. Diesel Emissions. The example of diesel engines and emissions nicely illustrates simultaneous U.S. and European precaution regarding different risks. The United States tightly regulates diesel engines to reduce human exposure to fine particulate matter, ${ }^{96}$ while Europe promotes diesel engines to reduce carbon dioxide emissions and global warming. Both policies are precautionary, but against different-and directly countervailing-risks.

b. Mad Cow Disease (Bovine Spongiform Encephalopathy $(B S E))$. Another example of simultaneous but differing precaution involves BSE. ${ }^{97}$ The United States banned the import of British beef in 1989, several years before the EU adopted such a ban. ${ }^{98}$ The EU has since lifted its ban-and sued France in the ECJ to force France to lift its ban $^{99}$-while the U.S. ban remains in place. Meanwhile, however, Europe has adopted somewhat more stringent policies than the United States regarding the kinds of protein matter that can be fed to cattle and sheep. On the other hand, in 1999 the FDA adopted a "Precautionary Measure" that prohibits blood banks from collecting blood from donors who have spent six months or more in the United Kingdom. ${ }^{100}$ In 2001, the FDA went further, rejecting any donor who

95. See generally CHRISTOPHER HOOD, HENRY RothSTEIn, \& ROBERT BALDwin, The GOVERNMENT OF RISK: UNDERSTANDING RISK REGULATION REGIMES (2001) (demonstrating considerable variation across risk regulation regimes within Great Britain).

96. See Katharine Q. Seelye, Administration Approves Stiff Penalties for Diesel Engine Emissions, Angering Industry, N.Y. TIMES, Aug. 3, 2002, at A11.

97. For further discussion, see generally Wiener \& Rogers, supra note 10.

98. See generally Wiener \& Rogers, supra note 10.

99. CEC v. French Republic, discussed supra note 43.

100. See U.S. Department of Health and Human Services, Food and Drug Administration, Guidance for Industry: Revised Precautionary Measures to Reduce the Possible Risk of Transmission of Creutzfeldt-Jakob Disease (CJD) and New Variant Creutzfeldt-Jakob Disease (vCJD) by Blood and Blood Products (Aug. 17, 1999)), at http://www.fda.gov/cber/guidlines. 
had spent three months or more in the United Kingdom or five years or more anywhere in Europe since 1980. ${ }^{101}$ The FDA acted despite recognizing that there have been no studies showing human blood transmission of the human form of BSE, variant Creutzfeldt-Jakob Disease (vCJD), only conflicting animal data, and no cases yet of vCJD in the United States; ${ }^{102}$ that the "transmissibility of vCJD by blood or blood products is unknown" and "transmissibility [of vCJD] cannot confidently be predicted from studies of CJD;","103 and that "No transmission of CJD or vCJD by human blood components or plasma derivatives has been documented to date."104 European officials considered the risk "theoretical" and "very small" at the most. ${ }^{105}$ But the FDA said that "[u]ntil more is known about the possibility of vCJD transmission by blood components or plasma derivatives, a precautionary policy of withdrawal for all of these products is recommended for material from donors with vCJD."106

The boldness of this precautionary move is evident from the countervailing risk it creates: a shortage of blood for use in hospital operating rooms. Blood supply in the United States is already very short. The Red Cross testified to the FDA that the 1999 policy would likely reduce the pool of eligible donors by about two percent, concentrated among the group of frequent repeat donors who account for a large share of donated blood, ${ }^{107}$ and the 2001 policy would reduce the blood supply by five to eight percent. ${ }^{108}$ Blood shortages would be severe in New York City: in addition to losing eight percent of its U.S. donors, New York would lose the 25 percent of its blood supply that is imported from European donors who would be banned

htm (last visited Mar. 5, 2003) (hereinafter Guidance for Industry).

101. See Raymond Hernandez, Citing Disease, F.D.A. Panel Backs Blood Donor Curbs, N.Y. TIMES, June 29, 2001, at B3. The revised policy is U.S. Department of Health and Human Services, Food and Drug Administration, Guidance for Industry: Revised Preventive Measures to Reduce the Possible Risk of Transmission of Creutzfeldt-Jakob Disease (CJD) and Variant Creutzfeldt-Jakob Disease (vCJD) by Blood and Blood Products (January 2002), at http://www.fda.gov/cber/gdlns/cjdvcjd.htm (last visited June 10, 2003).

102. See Guidance for Industry, supra note 100, at part II.

103. Id. at part II.B.

104. Id. at part V.B.

105. John Tagliabue, US Plan to Halt Blood Imports Worries Europe, N.Y. TIMES July 17, 2001 , at A1.

106. Guidance for Industry, supra note 100 at end of part II.B.

107. United States Food and Drug Administration, Advisory Committee on Transmissible Spongiform Encephalopathies, Hearings of 2 June 1999, SAG Corp. Transcript, at 46 (Statement of Dr. Williams), available at http://www.fda.gov/ohrms/dockets/ac/cber99.htm (last visited June 10, 2003).

108. Tagliabue, supra note 105. 
under the 2001 policy. ${ }^{109}$ These reductions in blood supply pose a high and fairly certain risk of death to those who need emergency blood during operations - in New York, a "disastrous ... public health crisis." 110 Europe has not adopted such stringent restrictions on blood donations, though it has undertaken leukodepletion on the theory that the disease agent (the prion) is more likely to be carried by white blood cells; and the United Kingdom has recently begun importing blood for young children. ${ }^{111}$ In short, the United States has been more precautionary regarding a risk of much greater impact and public concern in Europe.

c. Violence. Violence is an issue of public health and public policy. ${ }^{112}$ The conventional wisdom seems to be that Europe is more precautionary while the United States is a more risk-taking and violent society. ${ }^{113}$ Yet closer inspection reveals a more complex pattern. On some issues, Europe is more precautionary; on others, the United States is more precautionary. Indeed it is sometimes the very precautionary approach taken in the United States that can seem barbaric to Europeans. This examination illustrates further the weakness of simple cross-national comparisons. It also sheds new light on some of the drawbacks to aggressive precautionary regulation.

An oft-cited example of greater precaution in Europe is gun control. There appear to be far more guns available per household in the United States than in Europe; according to the UN, an estimated 41

109. $I d$.

110. $I d$.

111. See Wiener \& Rogers, supra note 10. Motivated in part by its scandal over HIV-tainted blood, France has banned blood donations by people who have spent one year or more in Britain. See Kenneth Lee, France Acts on Threat of BSE Transmission by Blood, THE SCIENTIST, Jan. 23, 2001, available at www.biomedcentral.com/news/20010123/05/ (last visited July 3, 2003). The U.S. policy is tighter: three months in Britain or five years anywhere in Europe.

112. See World Health ORganization, World Report on Violence and Health (2002), available at http://www5.who.int/violence_injury_prevention/main.cfm? $\mathrm{p}=0000000117$ (treating violence as a public health issue); PHILIP J. COOK \& JENS LUDWIG, GUN VIOLENCE: THE REAL COSTS (2000) (similar). In 1999 (the latest year for which final statistics have been reported), violence (including both homicide and suicide) accounted for approximately 45,000 deaths or about 2 percent of annual fatalities in the United States, with suicide claiming 29,199 lives and homicide claiming 16,889. See Donna L. Hoyert et al., Deaths: Final Data for 1999, National Vital Statistics Report, Vol. 49, No. 8 (September 21, 2001) at 6 \& Table C, available at http://www.cdc.gov/nchs/data/nvsr/nvsr49/nvsr49_08.pdf (last visited June 10, 2003). Meanwhile, "[i]n 1999 a total of 28,874 persons died from firearm injuries in the United States . . . Firearm suicide and homicide, the two major component causes, accounted for 57.5 and 37.5 percent, respectively, of all firearm injury deaths in 1999 [with firearms accidents accounting for 2.9 percent]." Id. at 10.

113. See Daley, supra note 37. 
percent of U.S. households have at least one firearm, compared to only 10 percent in Germany, 4 percent in the United Kingdom, 8 percent in Denmark, and 20 percent in Sweden. ${ }^{114}$ Most European countries have national gun licensing requirements, whereas the United States does not. ${ }^{115}$ The United States has only recently adopted the Brady Act requiring background checks, part of which was declared unconstitutional, ${ }^{116}$ and the rest of which has been criticized as incomplete (for example, for failing to cover gun shows).

The rate of gun homicides per 100,000 population is estimated at roughly 6 to 7 in the United States, compared to only 0.4 in France, 0.2 in Germany, 0.1 in the United Kingdom, 0.2 in Denmark, and 0.2 to 0.3 in Sweden. ${ }^{117}$ Whereas gun homicides account for about twothirds to three-quarters of homicides in the United States, they account for only about one-third of homicides in France and about onefifth to one-tenth of homicides in Germany, the United Kingdom, Denmark, and Sweden. ${ }^{118}$ When gun-related suicides and accidents are added to homicides, the rate of gun deaths per 100,000 population is estimated at 14 in the United States, compared to only 1.5 in Germany, 0.5 in the United Kingdom, and 2.3 in Sweden. ${ }^{119}$

To be sure, these gun death statistics do not necessarily demonstrate that more stringent gun control laws would reduce gun violence in the United States (nor that it is gun laws that have prevented higher gun death rates in Europe). ${ }^{120}$ There is a spirited debate whether laws restricting gun ownership are effective in reducing gun deaths or actually increase gun deaths. ${ }^{121}$ All that these comparisons

114. See United Nations, International Study on Firearm Regulation 52-53 (1998).

115. Id. at 52-53. Yet states of the United States may have their own licensing systems; the appropriate comparison to a United States national license requirement would be a Europewide EU license requirement, which does not yet exist.

116. See Printz v. United States, 521 U.S. 898 (1997) (holding that United States federal government cannot constitutionally "commandeer" local law enforcement officers to enforce federal background check requirements).

117. United Nations, International Study on Firearm Regulation 179-181 (1998).

118. Id.

119. Id. at 108-109.

120. Cf. Setsuo Miyazawa, The Enigma of Japan as a Testing Ground for Cross-Cultural Criminological Studies, in COMPARING Legal Cultures 195 (David Nelkin ed. 1997) (describing complexities in comparing criminal laws across cultures, though rejecting many culturespecific theories of low crime in Japan).

121. Compare COOK \& LUDWIG, supra note 112 (finding that gun controls reduce violence), and Evaluating Gun Policy: EFFECTS ON CRIME AND Violence (Jens Ludwig \& Philip I. Cook eds. 2003) (similar, including critiques of work by John Lott), with JOHN R. LOTT, JR., MORE Guns, LESS CRIME: UNDERSTANDING CRIME AND GuN-CONTROL LAws (1998) (finding that gun controls increase violence and concealed weapons permits reduce violence) and 
suggest is that Europe has adopted a more precautionary, ex ante regulatory approach which restricts the spread of guns. It is a precautionary strategy precisely because it has been adopted under debate and uncertainty about the risks of wider gun ownership and the effects of the ostensibly preventive laws restricting gun ownership.

By contrast, in the 1990's the United States undertook a more precautionary approach to youth violence. Punishments for juvenile offenders were made more severe in the United States than in Europe. Among other examples, the United States allows longer prison terms for juveniles than do most European countries, ${ }^{122}$ and the United States allows convicts to be executed for murders committed before adulthood whereas Europe does not. ${ }^{123}$

The United States generally allows juvenile offenders to be tried as adults at earlier ages than do European legal systems. ${ }^{124}$ Over the last decade, U.S. states have been revising their laws to enable or require prosecution of youths as adults at earlier ages, to increase sentences for juvenile offenders, and to reduce the confidentiality of juvenile offenders' records. ${ }^{125}$

John R. Lott, JR., The Bias Against Guns: Why Almost Everything You've HeARD ABOUT GUN CONTROL IS WRONG (2003) (arguing that advocacy of gun control is biased).

122. See generally JuVEniLe Justice Systems: InTERnAtional PERsPectives (John A. Winterdyk ed. 1997) (comparing penalties for juvenile crime across numerous countries).

123. See Stanford v. Kentucky, 492 U.S. 361 (1989); Sara Rimer \& Raymond Boner, Young and Condemned: Whether to Kill Those who Killed as Youths, N.Y. TIMES, Aug. 22, 2000, at A1 (reporting plans in the year 2000 to execute five people who committed murder before age 18; and noting that the European Union views this practice as morally repugnant). But see Joshua Micah Marshall, Death in Venice: Europe's Death-Penalty Elitism, THE NEw REPUBLIC, July 31, 2000, at 12 (reporting that public attitudes in Europe are just as favorable to capital punishment as they are in America, and attributing European condemnation of capital punishment to European government elites).

One might object that the death penalty is not "precautionary" because it is imposed ex post (after the murder). Advocates of capital punishment might respond that the death penalty is precautionary because it deters others, and because it incapacitates the murderer and thereby prevents future repeat behavior. (The latter a claim that is stronger the younger the executed felon.) If it is neither a deterrent nor an incapacitator, and is purely retributive, then the death penalty may well fall outside the class of precautionary criminal laws; and any argument for imposing the death penalty would be significantly weaker as well. The point here is only that the death penalty for those who committed juvenile murders is an early and extremely stringent government intervention intended at least in part to prevent uncertain future risks to public safety.

124. See Winterdyk ed., supra note 122; Christian Pfeiffer, Juvenile Crime and Violence in Europe, 23 Crime \& Justice 255, 311-322 (Nov. 1998).

125. See Patricia Torbet \& Linda Szymanski, State Legislative Responses to Violent Juvenile Crime: 1996-97 Update, US DEPT. OF JUSTICE, OFFICE OF JUVENILE JustiCE AND Delinguency Prevention, Juvenile Justice Bulletin, Nov. 1998; Margaret Talbot, What's Become of the Juvenile Delinquent?, N.Y. TIMES MAGAZINE, Sept. 10, 2000, at 41. 
These measures are precautionary because they attempt to intervene more stringently, and especially earlier, to incapacitate and deter young people from committing future violent acts-which are uncertain future risks. The future violence of juveniles is highly uncertain, and despite predictions in the 1980s of a coming wave of youth violence, the data do not show such an epidemic of youth violence occurring. ${ }^{126}$

Of course, these precautionary measures do not necessarily help to reduce juvenile crime. Prosecuting and imprisoning juveniles as adults might incapacitate some offenders but might also train some youths to be hardened recidivist criminals. ${ }^{127}$ Tough juvenile penalties are a precautionary strategy precisely because they have been adopted under uncertainty about the eventual risks of young felons as they mature. Like other precautionary strategies, tough juvenile penalties may prove to be protective or may yield countervailing risks that offset or even reverse the protective effects.

A related example is the treatment of sex offenders after release from incarceration. In the United States, the residence of these ostensibly dangerous persons can be publicized to neighbors, whereas in the United Kingdom the confidentiality of the recovering offender is maintained. ${ }^{128}$ At the same time, in the United Kingdom there is more widespread use of video monitoring cameras to record ordinary daily life in public places_intersections, shopping malls, parks_as a precautionary strategy to detect and deter crime. Such a policy had not been adopted in the United States, and might be held unconstitutional, but may now become increasingly practiced and accepted in the United States since the terrorist attacks of September 11, 2001.

Another example of U.S. precaution against future violence is the treatment of mentally ill persons who may pose a threat to themselves or others. The traditional approach has been reactive, arresting mentally ill persons only after they have committed a serious offense. Ex post intervention tolerated the risk of false negativespeople the police initially declined to arrest but who later turned out

126. See Franklin E. Zimring, The Youth Violence Epidemic: Myth or Reality?, 33 WAKE Forest L. ReV. 727 (1998); FrankLIn E. ZimRing, AMERICAN YOUTH ViolenCE, 3-16, 3165 (2d ed. 2001)

127. See Eric K. Klein, Note, Dennis the Menace or Billy the Kid: An Analysis of the Role of Transfer to Criminal Court in Juvenile Justice, 35 AM. CRIM. L. REV. 371 (1998).

128. See Christopher Hood \& Robert Baldwin, Why is Risk Regulated in Different Ways? Beyond the Risk Society Debate, RISK \& REGULATION (LSE-CARR on-line magazine), (viewed on Sept. 25, 2000) at http://www.lse.ac.uk/Depts.carr/n14.htm. Many U.S. states have enacted versions of "Megan's Law" requiring precautionary disclosure of former sex offenders' whereabouts. 
ple the police initially declined to arrest but who later turned out to cause harm. In an effort to prevent such violent acts before they occur, police and mental health workers in some cities, such as Los Angeles and Birmingham, have begun to work together to undertake more precautionary interventions. ${ }^{129}$ The program in Ithaca, New York is noted for its very early and collaborative interventions by police and mental health workers; there the goal is to approach apparently mentally ill persons before they have committed violence-“you solve problems even when they're not problems," 130 and "you don't know whether you prevented something or not." interventions result in hospitalization or incarceration of the ill person. Nationwide, a rising number of young mentally ill persons are incarcerated to prevent future violence. ${ }^{132}$ Although these proactive strategies can protect against future violence, that forecast is necessarily uncertain. There could be false positives-people labeled as mentally ill, and then treated or incarcerated, who would not have been violent in the future. And "such aggressive police involvement has a risk .... 'There is a potential invasiveness there for individuals who would feel coerced into mental health services'...." "“' "I]f it's done the wrong way it conjures up images of Big Brother at its worst." "134

These stringent and early applications of criminal law in the United States highlight the restrictions on personal freedom that can be associated with the precautionary principle. If the basic version of the PP were generally applied to human beings, scientific uncertainty about one's future criminality would not be an excuse to avoid present incarceration. If the burden-shifting version of the PP were applied to human beings, each of us would have the burden of proving to the government our future non-violence, or else we would be incarcerated until we could do so. In Philip K. Dick's marvelous story

129. See Laurie Goodstein, Trying to Prevent the Next Killer Rampage, N.Y. TIMES, Sept. 6, 2000, at A1.

130. Id. (quoting Terry Garahan, Ithaca N.Y. mental health worker).

131. Id. at $\mathrm{A} 18$ (quoting Garahan).

132. See Fox Butterfield, Concern Rising Over Use of Juvenile Prisons to 'Wharehouse' the Mentally Ill, N.Y. TIMES, Dec. 5, 2000, at A14.

133. Id. at A18 (quoting Henry J. Steadman, president of Policy Research Associates).

134. Goodstein, supra note 129, at A18 (quoting Ron Hornberg, director of legal affairs at the National Alliance for the Mentally Ill). Similarly, Judge Terry Friedman of Los Angeles County Juvenile Court says that "In essence, we are criminalizing mental illness . . because they are untreated, their illness leads them to act out, sometimes violently, so we lock them up ..." quoted in Butterfield, supra note 132, at A14. 
"Minority Report," 135 a future United States uses genetically engineered prescience to foresee and stop crimes before they happen by arresting and incarcerating would-be murderers. The story is a reverie about the dangers of gearing up the machinery of the state to implement precaution when there is always a risk of false positives.

Meanwhile, even apart from any concern for the imprisoned individual defendant, there are also countervailing risks to the public. The defendant's incarceration could mollify the citizenry but leave the true culprit at large, could generate future violent behavior (recidivism), and could displace other more violent persons from state custody. And high-speed police chases to catch fleeing felons (a precautionary measure to prevent future violence by the suspect) kill hundreds of bystanders every year. ${ }^{136}$

Perhaps a "truly" precautionary approach to violent crime would intervene even earlier than do gun control and the juvenile justice and mental health systems. Even more precautionary measures might include community policing, childhood education, aid to the indigent, jobs, and basic inculcation of moral virtues. Opportunity, social reciprocity, and hope might be cited as the most precautionary investments against future violence. True, but these apply to the health and environmental area as well: strong and virtuous social norms, community bonds, and economic opportunities tend to support sound environmental conservation. ${ }^{137}$ If the PP is an argument for investments in social norms and economic growth, it becomes so general that it loses its traction as a guide to regulatory policy. In any event, advocates of the PP use it to advocate legal rules restricting risky activities, not social values and improved prospects in general.

Of course, proponents of the PP do not usually advocate its ap-

135. See Philip K. Dick, The Minority Report And Other Classic Stories (reprinted Citadel Press 2003). The story became a movie starring Tom Cruise as "Precrime" chief detective John Anderton. In both the story and the movie, Anderton finds himself predicted to commit a murder, and he knows the prediction to be a false positive. His dilemma is whether to resist his fate, revealing a flaw in the prediction and leading to the dismantling of the Precrime regime, or to commit the murder anyway, sacrificing himself (and his victim) to preserve the apparent accuracy of the prediction and thus keep Precrime in operation to protect others despite the risk of erroneous forecasts. The story and the movie resolve this dilemma differently, underscoring the vexing problem of false positives.

136. See Jonathan B. Wiener, Managing the Iatrogenic Risks of Risk Management, 9 RISK: HEALTH SAFETY ENVIRONMENT 39, 39-42 (1998).

137. See Elinor Ostrom, Governing the Commons (1990); Robert Ellickson, ORder Without LAW (1993); Robert T. Deacon, Deforestation and the Rule of Law in a Cross Section of Countries, 70 LAND ECON. 414-430 (1994) (showing that hope and economic security reduce deforestation). 
plication to crime suspects or to the regulation of human beings. Talbot Page drew a sharp opposition between environmental law and criminal law, advocating the standard presumption of "innocent until proven guilty" for prosecutions of suspected violent criminals but a reversed presumption of "guilty until proven innocent" for precaution against uncertain environmental risks. ${ }^{138}$ Page argued that both types of precaution would benefit public health, but that the cost of criminal precaution would be freedom (valued more than health), while the cost of environmental precaution would only be money (valued less than health). Yet the prospect of countervailing risks, ${ }^{139}$ neglected by Page, means that the cost of environmental precaution could also be health; and the prospect of restrictions on freedom (including criminal sanctions) to enforce health and environmental protections means that the cost of environmental precaution could also be freedom. Thus even if one accepts Page's hierarchy of valuesfreedom trumps health trumps money ${ }^{140}$ - this premise does not clearly favor environmental precaution. And the PP is meant to be a broadly applicable principle of government law and policy to prevent uncertain threats to health and safety. At its annual convention in February 2000, the American Association for the Advancement of Science (AAAS) held a full-day session on the PP titled "The Precautionary Principle: When is it Appropriate to Presume 'Guilty Until Proven Innocent'?" All precautionary regulations restrict human beings in some way-that is what regulation means. To a significant degree, everyone (liberals and conservatives alike) wants the state to restrict the ability of one person to be a source of risk to others, whether by his own hands (violence) or by the technologies he deploys (e.g., automobiles or chemicals or electric power or beef). If the PP must retreat each time an area of important risk regulation turns out to restrict individual choice, then the PP is not much of a general principle. Or, more constructively, examples such as violent crime help make more plain that precautionary regulation has disadvantages as well as advantages, which in turn helps us recognize

138. Talbot Page, A Generic View of Toxic Chemicals and Similar Risks, 7 ECOLOGY L. Q. 207 (1978).

139. See Graham \& WIENER, RISK Vs. RISK, supra note 70; Wiener, Multirisk World, supra note 11; Wiener, Managing the Iatrogenic Risks of Risk Management, supra note 136.

140. An argument similar to Page's is made by Mark Geistfeld, Reconciling Cost-Benefit Analysis with the Principle that Safety Matters More than Money, 76 N.Y.U.L. Rev. 114 (2001), and used to advocate precaution in Mark Geistfeld, Implementing the Precautionary Principle, 31 ENVTL. L. REP. 11326 (Nov. 2001). Like Page, Geistfeld analyzes a decision to confront a single risk and neglects the world of multiple risks in which precautions may themselves increase countervailing risks to health and safety. 
advantages, which in turn helps us recognize this reality in the health and environmental arena.

d. Terrorism. ${ }^{141}$ In September 2002, President Bush formally announced a new U.S. doctrine of preemptive self-defense, promising that the United States will use preemptive military strikes to thwart threats of terror and mass destruction. His policy provides that "America will act against such emerging threats before they are fully formed.... The greater the threat, the greater is the risk of inaction and the more compelling the case for taking anticipatory action to defend ourselves, even if uncertainty remains as to the time and place of the enemy's attack." 142 Similarly, in a speech at West Point on June 1, 2002, he said: "if we wait for threats to fully materialize, we will have waited too long." 143 On that view, the Bush administration pressed ahead with preemptive military intervention in Iraq and aggressive investigative and monitoring policies at home.

This new doctrine, and the prospect of U.S. strikes against Iraq before UN weapons inspectors found a "smoking gun," sparked a renewed critique of alleged American unilateralism (following outrage over U.S. rejection of the International Criminal Court, the Kyoto Protocol, and other multilateral accords), and a new resentment at the lone superpower perceived as acting aggressively and prematurely, before the evidence is in. German Foreign Minister Joschka Fischer, whose Green party narrowly won reelection to the governing coalition in part by sharply criticizing U.S. aggressiveness toward Iraq, worried aloud on September 14, 2002 to the UN General Assembly: "to what consequences would military intervention lead? ... Are there new and definite findings and facts? Does the threat assessment justify taking a very high risk? ... we are full of deep skepticism regarding military action...." ${ }^{144}$ While the U.S. government wants fast and forceful action to prevent the next terrorist attack, its detractors in Europe want more evidence and deliberation before

141. On the relevance of terrorism to regulatory policy, see Eric A. Posner, Fear and the Regulatory Model of Counterterrorism, 25 HARV. J. L. \& PUB. POL. 681 (2002).

142. The National Security Strategy of the United States of America, September 17, 2002, Introduction \& Part V, at http://www.whitehouse.gov/nsc/nss.html (last visited March 1, 2003).

143. Remarks by the President at 2002 Graduation Exercise of the United States Military Academy, West Point, New York, June 1, 2002, at http://www.whitehouse.gov/news/releases/ 2002/06/20020601-3.html (last visited March 1, 2003).

144. Address by Joschka Fischer, Minister for Foreign Affairs of the Federal Republic of Germany, at the Fifty-seventh Session of the United Nations General Assembly, New York, Sept. 14, 2002, available at http://www.auswaertiges-amt.de/www/en/aussenpolitik/index_html (visited March 6, 2003). 
acting. British Prime Minister Tony Blair and U.S. Secretary of State Colin Powell attempted to make that case in early 2003. Still, France and Germany opposed intervention. Many Americans became exasperated with European opposition to precautionary U.S. action in Iraq, ${ }^{145}$ just as Europeans have resented U.S. opposition to environmental precaution. Now, after the war in Iraq and the failure (so far) to find compelling evidence that Iraq was creating or deploying weapons of mass destruction, critics question whether the United States and Britain acted prematurely ${ }^{146}$-in effect, whether the United States and Britain "cried wolf" and undertook precaution based on a false positive.

But the terrorism example illustrates that the new U.S. doctrine of preemptive self-defense is based on the same logic as the precautionary principle. In advocating precaution, European leaders-especially Greens-make the same point that President Bush has made about terrorism: if we wait to confirm that the threat is real, it will be too late. The European Environment Agency advised in January: "forestalling disasters usually requires acting before there is strong proof of harm." 147 Said the EU's Environment Commissioner, Margot Wallstrom, on April 25, 2003: "if you smell smoke, you don't wait until your house is burning down before you tackle the cause." wise nongovernmental advocates of the precautionary principle say: "sometimes if we wait for proof it is too late. ... If we always wait for scientific certainty, people may suffer and die, and damage to the natural world may be irreversible." ${ }^{149}$ These are almost verbatim the same justifications given by President Bush for preemptive intervention to fight terrorism. The United States, under both Presidents Bush and Clinton, criticized the precautionary stance as applied to health and environmental risks and sued in the WTO to block precautionary regulations. But President Bush would invoke precaution.

145. See Timothy Garton Ash, Anti-Europeanism in America, NeW York REV. OF Books, February 13, 2003, available at http://www.nybooks.com/articles/16059.

146. See Paul Krugman, Who's Accountable, N.Y. TIMES, June 10, 2003, at A27 (arguing that the treat of WMD in Iraq was exaggerated in order to justify intervention).

147. European Environment Agency, Late Lessons from Early Warnings, supra note 22, at 13 (2002).

148. Margot Wallstrom, US and EU Environmental Policies: Converging or Diverging?, Speech to the European Institute (April 25, 2002). Transcript available at http://europa. eu.int/rapid/start/cgi/guesten.ksh?p_action.gettxt=gt\&doc=SPEECH/02/184|0|AGED\&lg=EN\& display $=$ (last visited March 4, 2003)

149. The Science and Environmental Health Network, "Frequently Asked Questions," at http://www.sehn.org/ppfaqs.html (last visited March 1, 2003). 
Hence it is not that the EU endorses precaution and the United States rejects precaution. The Bush doctrine of preemption is, in effect, precaution applied to terrorism. It is aggressive action to preempt the serious and potentially irreversible risks of weapons of mass destruction (WMD) in Iraq, despite inconclusive evidence of that risk. And the criticisms from Europe and elsewhere of the Bush administration's anticipatory war on terrorism are the same arguments that industry makes in response to advocates of regulatory precaution: the evidence is uncertain, so we should not act. Thus the reality is that the United States and Europe both endorse precaution, just regarding different risks; and both criticize precaution when applied to risks they discount. Currently, Europe seems especially concerned about food safety and climate change, while the United States seems especially concerned about violence (both domestic and foreign) and local air pollution. Obviously, however, there is much variation within Europe regarding precaution against terrorism and WMD in Iraq: France, Germany, and Russia opposed such action, but Britain, Spain, Italy, and Poland favored it. And within the domain of risks of terrorism and WMD, it is plausible that the United States, France, and other countries would each make different judgments about precautionary interventions in different target countries, such as Afghanistan, Iraq, Iran, Syria, and North Korea. If so, one could not even say that the United States favors precaution against terrorism and France opposes it; the answer for each would depend on the context of action in each target country-the risks of inaction and benefits of action (weighted by the uncertainty of the evidence), the costs of action, and the countervailing risks of action. ${ }^{150}$

One good reason for each side's worries about the other side's precautions is that there can be real risks to precaution, whether military or regulatory-not just financial costs, but health and safety risks as well. Military intervention typically causes some "collateral damage" to civilians, as well as risking reprisals by those attacked. Giving airline pilots guns to stop terrorists may lead to inflight accident, theft, or misuse. As noted above, regulation also generates countervailing risks. For example, bans on genetically modified foods may perpetuate the use of chemical pesticides and hunger in poor coun-

150. I am grateful to Bruce Jentleson for discussion of this point. See Peter Feaver, Different Medicines for Different Maladies, RALEIGH News \& OBSERVER, Jan. 12, 2003, Opinion section, at 1 (arguing that adopting different policies for dealing with Iraq and North Korea is wise and does not reflect inconsistency or hypocrisy because the risks, benefits and costs of intervention in each country differ). 
tries. The U.S. FDA's precautionary measures to safeguard the blood supply against BSE may reduce the availability of blood in hospital emergency rooms. Forestalling climate change by shifting to fuelefficient diesel engines may increase local air pollution. Every protective intervention-military, regulatory, or medical-also runs the risk of causing new harms. ${ }^{151}$

3. Explaining the Pattern. Ultimately, what is interesting about this complex pattern is not whether one society is more precautionary or environmentalist or aggressive or morally upstanding than the other in general, but why societies choose to worry about different risks in particular. Several hypotheses can be advanced to answer this question. ${ }^{152}$ The choice of which risks to regulate may derive from real differences in the seriousness of different risks in different places. Or, as Oscar Wilde insinuated, it may arise from different cultures and risk perceptions, including heuristic reactions to recent crises. ${ }^{153}$ It may turn on differences among domestic political systems and shifting strengths of contemporary political actors, including the roles of separation-of-powers versus parliamentary systems, third parties (including the Greens), nongovernmental advocacy groups, and industry pressure and rent-seeking (including international trade protectionism and domestic trade rivalry). ${ }^{154}$ It may stem from different background legal systems, including the role of tort law; the United States may doubt the merits of precaution because it lacks Europe's tandem principle of proportionality to confine the reach of precaution, or because it has a more vigorous system than does Europe of ex post tort liability to catch residual risks. ${ }^{155}$ Or advocacy of precaution on the environment (and critique of precaution against terrorism) may be on the rise in Europe as part of a move to consolidate the power of European institutions, as against both the Member States internally and the United States externally. ${ }^{156}$ Or it may spring from

151. See GRAHAM \& WIENER, RISK VS. RISK, supra note 70.

152. For expanded discussion of these hypotheses, see Wiener \& Rogers, supra note 10, at $334-42$.

153. See Cross-Cultural Risk Perception: A Survey of EMPIRICAl Studies (Ortwin Renn \& Bernd Rohrmann eds. 2000); Elke U. Weber \& Christopher K. Hsee, Culture and Individual Judgment and Decisionmaking, 49 APPLIED PSYCHOLOGY: AN INTERNATIONAL REVIEW 32-61 (2000); MARY DOUGLAS \& AARON WILDAVSKY, RISK AND CULTURE: AN ESSAY ON THE SELECTION OF TECHNiCAL AND ENVIRONMENTAL DANGERS (1982); Cass R. Sunstein, Beyond the Precautionary Principle, 151 U. PA. L. REV. 1003 (2003).

154. See Wiener \& Rogers, supra note 10, at 336-37; Giandomenico Majone, The Principle of Precaution in Politico-Institutional Context, draft of June 2003 (copy on file with the author).

155. Id. at 340-42.

156. See Christian Joerges, Law, Science And The Management Of Risks To Health At The 
changing positions in global geopolitical strategy. ${ }^{157}$

But to fit the observed complex pattern, any or all of these explanations would have to predict heterogeneous policy choices in both the United States and Europe, not a simple contrast between all U.S. and all European policies. Hypotheses that contrast a typical European approach to a typical U.S. approach will be insensitive to variations and reversals within each, and over time, yet that is what we see occur. ${ }^{158}$ Identifying the probative explanatory variables driving the observed complex pattern of relative precaution is a prime question for further research. ${ }^{159}$

\section{E. Choice of Policy Instruments}

In the past there had been some divergence between the United States and Europe in the choice of policy instruments, but the future portends increasing convergence. Both the United States and Europe have employed best available technology (BAT) approaches for many years. But the United States has made increasing use of emissions trading (tradable permit) policies to deal with problems including lead in gasoline, CFCs, acid rain, land development, and water pollution, while Europe has not; and Europe has made greater use of emissions taxes than has the United States. ${ }^{160}$ Of late there appears to have been some convergence, especially as the EU has made greater use of emissions trading-in particular to control greenhouse gas emissions under the Kyoto Protocol. ${ }^{161}$ But the United States has not

National, European And International Leve l- Stories On Baby Dummies, Mad Cows And Hormones In Beef, 7 Colum. J. Eur. L. 1, 14-20 (2001); Giandomenico Majone, What Price Safety? The Precautionary Principle and its Policy Implications, 40 J. COMMON MKT. STUD. 89, 107 (2002).

157. See Kagan, supra note 40: the United States and Europe "disagree about what constitutes a threat ... [they] differ most these days in their evaluation of what constitutes a tolerable versus an intolerable threat."

158. We see variation in relative precaution against diverse risks and over time between the United States and the EU, within each of them, and within the member states of each. $C f$. HOOD ET AL., THE GOVERNMENT OF RISK, supra note 95 (finding variation across risk regulation regimes within the UK); Vogel, Ships Passing, supra note 33 (finding variation and reversal in relative U.S. and European precaution over time).

159. See Wiener \& Rogers, supra note 10, at $334-42$ (discussing and criticizing several major explanatory possibilities).

160. See Richard B. Stewart, Environmental Law in the United States and the European Community: Spillovers, Cooperation, Rivalry, Institutions, 1992 U.CHI. LEGAL F. 41, 75-80 (1993). See generally NEW INSTRUMENTS FOR ENVIRONMENTAL POLICY IN THE EU (Jonathan Golub ed. 1998); Jos Delbeke \& Hans Bergman, Environmental Taxes and Charges in the EU in Jonathan Golub ed., supra, at 242-260; Mikael Skou Anderson, GOVERNANCE BY GREEN TAXes: MAKING POLlution PREVEnTION PAy (1994).

161. Commission of the European Communities (CEC), Proposal for a Directive of the 
yet begun to make widespread use of emissions taxes. ${ }^{162}$

It should be noted here that the use of "economic incentives" is not a move to favor "economic interests" over environmental interests. In fact, industry often resists the use of taxes or emissions trading because those instruments, unlike technology standards, force industry to pay for every residual unit of emissions, either as a tax levy or as the foregone earnings from not selling a permit. Nor is the advocacy of "market-based instruments" based on the premise that "the market" can solve all environmental problems; it is rather an effort to correct what are recognized to be market failures by adopting government policies that reconstitute incentives in environmentally desirable directions. Moreover, the choice of instruments, such as economic/market-based incentives, is distinct from the choice of the level of environmental protection to be achieved. One can employ economic incentives to achieve quite stringent goals.

Information disclosure is an instrument that has been used more frequently in the United States than in Europe. ${ }^{163}$ On top of its "discovery" procedures in civil litigation, the United States has enacted several powerful information policies, including the 1966 Freedom of Information Act, the environmental impact statement requirements of NEPA in 1969, the 1986 enactment of the national Toxics Release Inventory and of California's Proposition 65, and the facility accident scenario requirements of Clean Air Act section 112r adopted in 1990. In turn, Europe has recently been moving to bolster its information disclosure policies through CEC Directive 1990/313/EEC on access to information from Member States, the 1998 Aarhus Convention, Regulation (EC) 1049/2001 of 30 May 2001 on access to information from EU institutions, the new European Pollutant Emissions Registry created in 2000 to be operational by 2003, and the pending Draft Protocol on Pollutant Release and Transfer Registers (PRTR) to be fi-

European Parliament and of the Council Establishing a Scheme for Greenhouse Gas Emission Allowance Trading Within the Community and Amending Council Directive 96/61/EC, COM(2001)581final, Brussels, 23 October 2001 (hereinafter CEC, Greenhouse Gas).

162. A comparison of U.S. and European instrument choice is currently being studied by a multiauthor group convened by Winston Harrington and Richard Morgenstern at Resources for the Future (RFF) in Washington DC; their book is forthcoming. See also Katrina M. Wyman, Why Regulators Turn to Tradeable Permits: A Canadian Case Study, 52 U. TORONTO L.J. (2002) (arguing that greater cost savings, not legal culture, leads countries to use market-based incentives to address particular problems - such as air pollution in the United States and fisheries conservation in Canada-but not others-such as air pollution in Canada and fisheries conservation in the United States).

163. See supra note 90; Sand, Precautionary Principle, supra note 24; Sand, Information Disclosure, supra note 90. 
nalized at the UN/ECE Ministerial Environmental Conference in Kiev in $2003 .{ }^{164}$

\section{F. Degree of Integration Across Hazards and Media}

U.S. environmental regulation is highly fragmented, with many different agencies implementing many different statutes to address different risks. Even within the EPA, there are separate fiefdoms for air, water, and waste. ${ }^{165}$ This fragmentation contributes to crossmedia and cross-pollutant shifts, frustrating effective regulation. ${ }^{166}$ "Integrated pollution control" (IPC) is the effort to deal with multiple risks more holistically, to ensure actual environmental improvement. ${ }^{167}$ Since the early 1990s, the United Kingdom has made significant efforts to adopt integrated pollution control, especially in its 1990 and 1995 Environmental Protection Acts and its creation of an integrated pollution control agency. ${ }^{168}$ The U.K. approach has since been borrowed by other countries in Europe and by EU institutions. ${ }^{169}$ A recent review of IPC in the United States and Europe concluded that "implementation of the integrated concept has proven to be very difficult, and examples of a truly holistic multimedia permit can rarely be found," 170 that most EU Member States had not implemented the IPPC Directive in their domestic law by the 1999 deadline, ${ }^{171}$ but that nonetheless "the European Union is at a somewhat

164. Sand, Information Disclosure, supra note 90. The draft PRTR Protocol to the Aarhus Convention was adopted at Kiev on May 21, 2003, along with two other UN/ECE protocols; see the press release at http://www.unece. org/press/pr2003/03env_p16e.htm (last visited June 11, 2003).

165. Alfred Marcus, EPA's Organizational Structure, 54 LAW \& CONTEMP. PROBS. 5 (Autumn 1991).

166. See GRAHAM \& WIENER, supra note 70.

167. Lakshman Guruswamy, The Case for Integrated Pollution Control, 54 LAW \& ContemP. Probs. 41 (Autumn 1991); InTEgrated Pollution CONTROL (Nigel Haigh \& Irene Erwin eds. 1990).

168. Albert Weale, Environmental Regulation and Administrative Reform in Britain, in Regulating Europe 106 (Giandomenico Majone ed. 1996); Michael Purdue, Integrated Pollution Control in the Environmental Protection Act 1990: A Coming of Age of Environmental Law? 54 MoD. L. REV. 534 (1991); Neil Carter \& Philip Lowe, The Establishment of a CrossSector Environment Agency, in UK ENVIRONMENTAL POLICY IN THE 1990s 38 (T. Gray ed. 1995).

169. Integrated Pollution PreVention ANd Control: The EC Directive From A Comparative Legal AND Economic Perspective (Chris Backes \& Gerrit Betlem eds. 1999); Johannes Zöttl, Towards Integrated Protection of the Environment in Germany? $12 \mathrm{~J}$. ENVTL. L. 281 (2000).

170. Uwe M. Erling, Approaches to Integrated Pollution Control in the United States and the European Union, 15 TULANE ENVTL. L.J. 1, 4 (2001).

171. Id. at $40-41$. 
more advanced stage" of IPC than the United States. ${ }^{172}$

\section{G. Enforcement Mechanisms}

The "styles" of U.S. and European regulation have long been said to diverge. The U.S. regulatory system is seen as highly legalistic and adversarial, with a strong role for decentralized decisionmaking in courts both in the review of regulation, and in the application of tort law. ${ }^{173}$ U.S. regulatory authority is more fragmented than European regulatory authority, with multiple agencies, courts, committees, and levels of government all having a hand in and offering opportunities for public input into policy development. ${ }^{174}$ The European regulatory style is seen as more cooperative, hierarchical, and centralized. ${ }^{175}$ Even when substantive standards are equivalent, procedural approaches are said to diverge significantly. ${ }^{176}$ U.S. adversarial legalism yields greater opportunities for formal public input and transparency, but also greater delay and antagonism; the European approach invites more negotiation of policy development between government and regulated businesses. ${ }^{17}$

This difference in style reflects the longstanding U.S. mistrust of concentrated power, in both government and business. ${ }^{178}$ The United

172. Id. at 41 .

173. See Kagan \& Axelrad eds., supra note 64. Centuries ago, Edmund Burke counseled the English Parliament to let the American colonies go because they were annoyingly litigious. See Edmund Burke, Speech on moving His Resolutions for Conciliation with the Colonies, March 22, 1775 , at $* * 89-90$, in SELECT WORKS OF EDMUND BURKE, AND MiscellaneOUS Writings (E.J. Payne ed. 1999) (noting that General Gage reports that "all the people in his government are lawyers, or smatterers in law; and that in Boston they have been enabled, by successful chicane, wholly to evade many parts of one of your penal capital constitutions.")

174. Id. at $12-13$.

175. See David Vogel, National Styles of Regulation: EnVIRONMENTAL Policy in Great BRitain AND the United States (1985); Jasanoff, Risk MANAGEMENT AND Political Culture, supra note 27; Kagan \& Axelrad eds., supra note 64, at 11-13.

176. See Kagan \& Axelrad eds., supra note 64, at 3, 23. Cf. Donald L. Horowitz, The Qu'ran and the Common Law: Islamic Law Reform and the Theory of Legal Change, 42 AM. J. COMP. L. 543 (1994) (observing that procedural law is often slower to converge across countries than substantive law because practicing lawyers cling to the procedure they know). But see Bernstein, supra note * (arguing that U.S. and German systems of civil procedure are hardly as divergent as is typically claimed-in particular, that German civil litigation does not position the judge as an inquisitorial actor but rather employs much the same adversarial method as does the United States). Kagan \& Axelrad's claim is not so much that the legal rules of civil procedure diverge, but that the social use of litigation to solve problems diverges.

177. See Kagan \& Axelrad eds., supra note 64, at 23, 404-05.

178. Id. at 10, 13; John C. Reitz, Standing to Raise Constitutional Issues, 50 AM. J. OF CoMP. L. 437, 457 (2002); Richard B. Stewart, A New Generation of Environmental Regulation? 29 CAP. U. L. REV. 21, 85-86 (2001) (hereinafter Stewart, New Generation). 
States Constitution has few principles obligating government to act; it articulates limited governmental powers and individual rights to block the government. Mistrust of governmental power may itself be a reason for U.S. reluctance to embrace the precautionary principle, while European legal culture may be more comfortable with principles of obligatory regulatory action.

The U.S. reliance on courts, both to enforce regulations at the behest of citizen suits and to award compensation to tort victims, may also help explain the disagreement between U.S. and European officials over adoption of an overarching precautionary principle. Knowing that the adversarial U.S. legal system would enforce such a principle more vigorously than European law, U.S. negotiators may resist agreeing to a principle that would seem more stringent in the United States than elsewhere. And knowing that the U.S. tort system is there to remedy injuries when they occur-and thereby to deter future injuries, U.S. officials may feel less need to adopt highly precautionary ex ante regulation. By contrast, European officials may worry less about vigorous and rigid enforcement of precaution, while they may feel they need it more because they lack as robust a tort system.

There are some signs of convergence regarding the style of enforcement. Europe is becoming more formal and legalistic, inviting greater participation by interest groups in policy formulation, in part as a consequence of the integration of European institutions and the rise of power in Brussels. ${ }^{179}$ European public trust in government and scientists has declined in the wake of several food safety crises, including mad cow disease, thereby prompting greater demands for regulatory transparency and accountability. ${ }^{180}$ Meanwhile, U.S. regulation is becoming less adversarial and more cooperative through the use of regulatory negotiation, alternative compliance agreements, habitat conservation plans, and Dutch-style environmental covenants. $^{181}$

\section{H. Hierarchical Level of Government (Regulatory Federalism)}

There had been divergence between the United States and Europe on the hierarchical or vertical level of government responsible for environmental regulation: U.S. policy had moved toward a

179. See Vogel, Risk Regulation, supra note 61; Kagan \& Axelrad eds., supra note 64, at 1415.

180. See Lofstedt \& Vogel, supra note 33.

181. See Golub ed., supra note 160; but see Stewart, New Generation, supra note 178, at 8586 (doubting how far the U.S. will go in this direction). 
strong role for the federal government, adopting national pollution control standards and enforcing them directly against private entities (though federal standards are often implemented by the states). Meanwhile, in Europe, the competency of the European Commission to address environmental issues took time to establish, and the principle of subsidiarity still left most standard-setting and enforcement decisions in the hands of Member State and provincial governments. But now there may be signs of some convergence, as the EU centralizes toward a stronger role for the Commission in Brussels and as the United States decentralizes toward a greater role for the states. ${ }^{182}$

\section{COMPARATIVE PRECAUTION AND EVOLUTION}

\section{A. Cautions Concerning Comparison}

Comparisons of national regulatory policies confront a series of difficulties. Recent efforts to compare U.S. and European environmental policies illustrate these pitfalls. Some problems derive from inadequate data collection, but others go deeper, questioning whether such comparisons are methodologically tractable at all.

First, comparisons of national regulatory policies frequently leap to macro-scale conclusions from just one or a few highly visible examples of conflict. For example, claims that "European policies are generally becoming more precautionary," if based only on the recent controversies over genetically modified (GM) foods and climate change, succumb to the availability heuristic ${ }^{183}$ - exaggerated attention to salient recent crises. They fail to study the broad array of comparative data upon which any such claims (in whatever direction) ought to be based. But even utterly objective observers may find it methodologically vexing to test the descriptive claim that one legal system is or is not more precautionary than the other. We cannot prove or disprove such broad empirical claims unless we can select and compare a representative sample of policies from the population of relevant regulatory actions. ${ }^{184}$ Yet drawing such a representative

182. See Breyer \& Heyvaert, supra note 66; Joerges, supra note 156.

183. On the availability heuristic and its distortion of perception, see Cass R. Sunstein, Beyond the Precautionary Principle, 151 U. PA. L. REV. 1003, 1008-11, 1041-44 (2003); Timor Kuran \& Cass R. Sunstein, Availability Cascades and Risk Regulation, 51 STAN. L. REV. 683-768 (1999); Howard Margolis, DeAling with Risk: Why THE PubliC AND THE EXPerts DisAGREE ON ENVIRONMENTAL IsSUES (1997); Roger G. Noll \& James E. Krier, Some Implications of Cognitive Psychology for Risk Regulation,19 J. LEGAL STUD. 747, (1990).

184. See Gary King, Robert O. Keohane \& Sidney Verba, Designing Social 
sample requires far more than noticing a handful of cases, such as beef hormones or GM foods, and asserting a broad difference. It requires defining the total regulatory universe or regulatory population from which to sample (e.g., from the environmental, health, and safety risks, or all three; what about financial risks?), identifying the boundaries of these populations (i.e., which specific regulatory policies do those categories embrace and exclude?), sampling from that population without bias (which subset of regulatory policies will approximately reflect the regulatory regime?); and defining a regulatory policy as the unit of observation (which units of policy make the proper basis for comparison-a statute, subprovision, agency regulation, court decision, enforcement action, or some combination thereof?). It is clear that relying on one or three cases is inadequate to support a broad system-wide claim. But a rebuttal based on a larger number of contrary or mixed cases, although a good start, is not necessarily sufficient to support the contrary system-wide claim. Thirty cases are better than three, but both sets are incomplete and subject to the critique that they are a skewed sample of the larger reality. It is a fair question whether comparative law can meet the criteria for rigorous social science. ${ }^{185}$

Second, comparisons written from one side of the Atlantic or the other frequently commit the comparativist's sin of ignorance of and even disrespect for foreign law, ${ }^{186}$ claiming, for example, that so much has happened over here while so little has happened over there, when the reality is hardly so one-sided. As Herbert Bernstein pointed out, "some American lawyers without a comparative background still suffer from parochial notions about the imagined uniqueness of certain features of their system which are not unique." 187 Herbert was criticizing Americans' claims of unique civil litigation systems, but the same criticism can apply to lawyers from any country who tout the system with which they are familiar and neglect the state of affairs in the other system. Sometimes this occurs inversely, with, say, Americans lionizing the European system and neglecting developments back home, or vice-versa. It is lopsided to assert, for example, that

INQUIRY (1994).

185. See William Blomquist, The Policy Process and Large- $N$ Comparative Studies, in THEORIES OF THE POLICY PROCESS 201, 221-24 (Paul A. Sabatier ed. 1999) (contending that comparative policy analysis requires models of high complexity, dynamism and within-country longitudinal detail that may be difficult to test with empirical data across countries).

186. John C. Reitz, How To Do Comparative Law, 46 AM. J. CoMP. L. 617, 636 (1998).

187. Bernstein, supra note*, at 589. 
Europe has enacted many important environmental measures since the 1980s while the United States has done little or has retrenched. ${ }^{188}$ The reality is that in the last two decades, while Europe indeed adopted many important measures, the United States, spanning Presidencies and Congresses of both major political parties, enacted the 1984 Hazardous and Solid Waste Amendments (including tough new controls on older waste treatment and disposal sites) at 42 U.S.C. $\S 6901$ et seq.; the 1986 Superfund Amendments (including tough waste site cleanup standards and the pathbreaking Toxics Release Inventory) at 42 U.S.C. $§ 11001$ et seq.; the 1990 Oil Pollution Act (including new technology requirements and liability standards for oil shipping) at 33 U.S.C. 2701 et seq.; the 1990 Clean Air Act Amendments (including tight technology controls on air toxics, and the very successful national $\mathrm{SO}_{2}$ allowance trading system for sharply reducing acid rain) at 42 U.S.C. 7401 et seq.; the 1996 Safe Drinking Water Act amendments at 42 U.S.C. 300f et seq.; the 1996 Food Quality Protection Act (PL 104-170, amending the Federal Insecticide, Fungicide and Rodenticide Act (FIFRA), 7 U.S.C. $\S 136$ et seq., and the Federal Food Drug and Cosmetic Act (FFDCA), 21 U.S.C. $\$ 301$ et seq.); the 1990s laws on youth violence and smoking in public places; and numerous stringent agency regulations (including the 1987 Top-Down BACT policy, the 1989 ban on British beef, the 1997 Ozone and PM2.5 national ambient air quality standards, the 2001 standard on arsenic in drinking water, and the 2002 and 2003 standards on diesel engine emissions). This is not to say that all of these policies have been desirable, nor that countries should compete to enact more laws; nor is it to ignore differences among Presidents. It is just to say that U.S. regulatory inactivity is not the reality. Likewise, there may have been more policy action in Europe in the 1970s than is typically recognized today. That is, after all, when the notion of precaution blossomed in German, Swedish, and Swiss environmental law.

Third, comparisons along one dimension, such as whether a particular principle (say, precaution) has been adopted in each legal system, frequently neglect the surrounding context of other principles, rules, institutions, and equivalent doctrines under other names, as well as the distinction between the law on the books and the law in action, ${ }^{189}$ so that the comparison falsely finds divergence when the reality in toto is functional similarity. For example, the claim that U.S.

188. See Kraemer, supra note 12.

189. See Reitz, supra note 186. 
regulation is now governed by cost-benefit analysis, while European regulation is not, neglects several contextual facts. To begin with, despite requirements for such analysis issued by every President since Jimmy Carter, including both Ronald Reagan and Bill Clinton, important areas of American regulation (such as the ambient air quality provisions of the Clean Air Act) remain statutorily immune to cost considerations. $^{190}$ Meanwhile, European regulatory policy has also moved to official cost-benefit or economic analysis, in the European Commission's Communication on the Precautionary Principle, ${ }^{191}$ and often in Member State law. ${ }^{192}$ And the "principle of proportionality" in European law amounts to a weighing of benefits and costs, conceptually equivalent to cost-benefit analysis (though perhaps less frequently quantitative in practice), that cabins the reach of the precautionary principle. ${ }^{193}$

Fourth, broad comparisons often neglect great variations within each legal system, such as among the EU Member States and among the states of the United States. In some cases that internal variation exceeds the claimed differences across two aggregated systems. ${ }^{194}$

Fifth, broad comparisons sometimes take a snapshot of current events but overlook dynamic changes through time, not only in the past but also into the future. Current events may seem to represent a climax or ending when in fact they are part of an ongoing transition that is difficult to perceive from within.

Sixth, and compounding the cautions stated above, may be the phenomenon of intergroup discrimination. This is the tendency of group members to assert sharp contrasts between one's own group and other groups, even when such differences are in fact minimal or nonexistent. Social psychologists have shown that group's members often assert such exaggerated intergroup contrasts even when the group members had only moments earlier been sorted into the groups

190. See, e.g., Whitman v. American Trucking Associations, 531 U.S. 457 (2001) (holding that cost-benefit analysis is impermissible under Clean Air Act sec. 109).

191. See Commission of the European Communities, Communication on the Precautionary Principle, supra note 21.

192. Sand, Precautionary Principle, supra note 24.

193. See Nicholas Emiliou, The Principle of Proportionality in European Law: A Comparative Study (1996); Case T-13/99, Pfizer Animal Health S.A. v Council, 2002 WL 31337, European Court of First Instance (2002), para. 410 ("The Court considers that a cost/benefit analysis is a particular expression of the principle of proportionality in cases involving risk management.").

194. See Hood ET AL., The Government OF RISK, supra note 95 (finding great variation across risk regulation regimes within the United Kingdom). 
at random-that is, when no such intergroup differences really exist. ${ }^{195}$ Groups sorted by ethnicity or race or nationality are even more prone to exaggerate intergroup contrasts, claiming own-group superiority along some dimension. ${ }^{196}$ Thus U.S. and European regulatory officials, and experts studying regulatory policy, may cite and emphasize transatlantic contrasts that would be nearly indistinguishable to outside observers, or at least far less salient than the similarities between U.S. and European regulatory policies. This is particularly likely with regard to relative precaution, where both the United States and Europe must lie at the highly precautionary end of the global spectrum. ${ }^{197}$ Debates between the United States and Europe over who is "more precautionary than thou" may look baffling and hairsplitting to the billions of people who live in countries with less stringent envi-

195. Henri Tajfel, Experiments in Intergroup Discrimination, 223 SCIENTIFIC AMERICAN 96-102 (1970). A related but distinct problem occurs when groups do not just exaggerate the stated contrasts with other groups, as Tajfel found, but actually become more polarized as they change their preferences and distance themselves further from the other group. See Cass R. Sunstein, Deliberative Trouble? Why Groups Go to Extremes, 110 YALE L.J. 71, 74 (2000); Roger BRown, Social PSYCHOLOGY 200-245 (2d ed. 1986). Groups become polarized in part when arguments among like-minded group members compound each other. Group polarization might also be occurring between U.S. and European regulatory communities, but as I argue below, the sharply stated contrasts between U.S. and European regulatory systems seem to be more rhetorical exaggeration than actual change in position.

196. See Donald L. Horowitz, ETHNiC GRoups IN CONFlict 144-147 (2d ed. 2000). Although examples of asserted (but inaccurate) racial and ethnic difference come immediately to mind, examples of geographic (often mixed with cultural) discrimination are also very common. For example, residents of America's two largest cities and their regions-New York in the Northeast and Los Angeles in Southern California - have long engaged in a rhetorical rivalry in which they assert sharp contrasts and demean the other place. Social scientists, however, argue that in fact the two places are actually very much alike, and increasingly so. They two cities are certainly more like each other than they are like the places in between them. "The New YorkLos Angeles dichotomy has long infected ... politics, culture, art and architecture, urban life. Taking sides seems practically a condition of citizenship ... Now a bicoastal detachment of social scientists is riding to the rescue. ... Partisans may be sorry to learn that ... [u]nder scrutiny, perceived polarities blur. ... Cherished assumptions about the two places turn out to be rooted less in reality than in myth." Janny Scott, East Coast, West Coast, and Where the Twain Meet, N.Y. TIMES, April 13, 2003 at A29.

197. Although this seems true, one cannot assume that developing countries always have less stringent health and environmental policies. Singapore, for example, may have one of the world's most precautionary legal regimes for avoiding health and environmental risks, including significant criminal penalties for public health infractions. See Wayne Arnold, In Singapore, 1970s Law Becomes Weapon Against SARS, N.Y. TIMES, June 10, 2003, at D5 ("'In your country [the U.S.], individual rights always take precedent [sic] over community rights. In our country, it's the other way around,' said Goh Kee Tai, chief of the communicable diseases branch at the Ministry of Health's epidemiology and disease control division. Singapore has a siege mentality about disease, much as it does about other security issues... The results are compelling. ... Singapore's life expectancy is higher than the United States'. Singapore is so clean that public health officials worry that its citizens have low resistance to even mild outbreaks.”) 
ronmental standards as compared to either the United States or Europe, less institutional capacity to enforce those standards, less scientific capacity to detect and warn of remote future risks, and much more pressing immediate crises in hunger, health, and environmental quality.

Seventh, flaws in comparative legal analysis may render it less an exercise in dispassionate social science than a vehicle for expressing the author's previously reached conclusion about what kind of law is desirable. ${ }^{198}$ Advocates of precaution may use the descriptive claim that Europe is now more precautionary than the United States in order to pressure both systems to ratchet upward their regulatory postures. Critics of precaution may make the same descriptive claim, that Europe is now more precautionary, in order to warn against such a trend in the United States.

In short, the fundamental fact of comparative legal analysis is that things are "more complicated than you thought." catchy depictions miss the true complexity and dynamism of vast and interactive social and legal systems. The same is true of regulatory policy itself: seductively simple prescriptions tend to fail when tested against the complexity of real-world systems. We need caution about precaution, and about comparisons of national precaution. That does not mean, however, that we should look only at the details and never step back to see the bigger picture; on the contrary, we must look at both details and whole systems. A main problem with the claimed contrasts between U.S. and European environmental policies is that they focus narrowly on one issue (such as the precautionary principle, or GM foods) and neglect the broader systems (such as the proportionality principle, tort law, and a broader sample of risks). Or they are really stories of institutional change (the growth and integration of European Community institutions) that deploy a few concrete examples to illustrate the story, implying without really demonstrating that the examples prove an across-the-board divergence in regulatory policy.

198. See KonRad Zweigert \& Hein Kötz, AN InTroduction to COMPARATIVE LAW 32 ( $3^{\text {rd }}$ ed. 1998) (counseling care in avoiding biased comparisons); Hiram E. Chodosh, Comparing Comparisons: In Search of Methodology, 84 IOWA L. REV. 1025 (1999) (criticizing comparative law as inadequately rigorous and subject to unstated biases); Gunter Frankenberg, Critical Comparisons: Re-thinking Comparative Law, 26 HARV. INT'L L. J. 411-455 (1985) (arguing that neutral comparison is impossible and must give way to self-reflection).

199. David Kennedy, New Approaches to Comparative Law: Comparativism and International Governance, 1997 UTAH L. REV. 545, 605 (1997). 


\section{B. Convergence, Divergence, and Hybridization}

Thus, to the question whether U.S. and EU environmental policies are converging or diverging, my answer is both and neither. U.S. and EU environmental policies are both converging and diverging, because the reality differs in different strata of policy development and implementation. ${ }^{200}$ And U.S. and EU environmental policies are neither converging nor diverging, because they are evolving simultaneously without a single endpoint in view for either system.

A more accurate model is one of "hybridization": iterative exchange of legal ideas, tools and approaches through a process not dissimilar to biological interbreeding among populations in nature. $\mathrm{Hy}$ bridization involves "legal borrowing" or "legal transplantation,",201 earlier called "mimesis"202 and more generally the diffusion of social concepts. $^{203}$ The social, cultural, or legal concepts exchanged are sometimes called "memes," ${ }^{204}$ as an analogy to the genes or traits exchanged in hybridization among biological populations. Hybridization in nature was long thought to be of minor evolutionary significance, but careful empirical investigations in the last few decades have revealed its widespread and often crucial role in survival and re-

200. Accord, Margot Wallstrom, US and EU Environmental Policies: Converging or Diverging? Speech to the European Institute (April 25, 2002). Transcript available at http://europa.eu.int/rapid/start/cgi/guesten.ksh?p_action.gettxt=gt\&doc=SPEECH/02/184101AG ED\&lg=EN\&display= (last visited March 4, 2003) (arguing that both are occurring).

201. Alan Watson, Legal Transplants: An Approach to Comparative LaW (2d ed. 1993). John Bell distinguishes transplants from "cross-fertilisation," which he says "implies a different, more indirect process [in which] external stimulus promotes an internal evolution within the receiving legal system [which] involves an internal adaptation ... a distinctive but organic product of that system rather than a bolt-on." John Bell, Mechanisms for Crossfertilisation of Administrative Law in Europe, in NEW DIRECTIONS IN EUROPEAN PUBLIC LAW 147, 147 (Jack Beatson \& Takis Tridimas eds. 1998). My conception of hybridization is sufficiently broad to encompass both transplantation and Bell's notion of cross-fertilisation, although I would have used the term "cross-fertilization," as in biology, to connote actual genetic transfer. Bell seems to envision relatively discrete legal systems which can either add-on foreign ideas (transplants) or respond internally to foreign ideas (cross-fertilisation); I envision legal systems as more diffuse with more permeable membranes through which legal ideas are regularly moving, so that both transplants and stimulus-response adaptations are forms of hybridization.

202. A.J. TOYNBEe, 12 A StUdy OF History: ReCONSIDERATIONS 343 (1961).

203. Torsten Hägerstrand, The Diffusion of Innovations, 4 INT'L ENCYCLOPEDIA OF SoCiAl SCIENCES 174 (1968). Peter Sand used the term "interfusion." See Peter H. Sand, Current Trends in African Legal Geography: The Interfusion of Legal Systems, in THE HARMONISATION OF AFRICAN LAW 107 (1974).

204. Richard Dawkins, The SELFISH GeNE (1976); Robert Aunger, The EleCtric MEME: A NEW THEORY OF HOW WE THINK (2002). 
production, as well as in the emergence of new species. ${ }^{205}$ In comparative regulatory policy, we both observe and participate in the exchange of legal traits or "legal DNA"; we can both document and shape the process.

This model of hybridization across legal systems describes one process of evolution of law. Much of the literature on legal evolution has described a different evolutionary process: the evolution within a legal system, involving the selection, refinement and replication of one legal system's legal rules over time. ${ }^{206}$ Another literature has focused on the exchange of legal ideas across legal systems. ${ }^{207}$ These two literatures seem rarely to have crossed paths and interbred. ${ }^{208}$ The relative inattention among many legal scholars to hybridization across legal systems parallels the relative inattention among many biologists, until recently, to hybridization across species.

When hybridization occurs, it can contribute to more efficient evolution than would purely within-system selection pressures. Exchange across species and across legal systems can foster success and efficiency by offering a wider array of choices; it helps diversify the

205. M.L. Arnold, Natural Hybridization And Evolution (1997); Peter R. Grant, ECOlOGY AND EVOLUTION OF DARWIN's FINCHES (1999); Peter Grant \& Rosemary Grant, Speciation and Hybridization in Island Birds, 350 PHILOSOPHICAL TRANSACTIONS OF THE ROYAL SOCIETY OF LONDON 765-72 (1996); DOLPH SCHLUTER, THE ECOLOGY OF ADAPTIVE RADIATION (2000).

206. See e.g. E. Donald Elliott, Law and Biology: The New Synthesis? 41 ST. LouIS U.L.J. 595 (1997) (reviewing the literature on Law and Biology and evolution of legal systems, including the hypothesis of efficient evolution through re-litigation of inefficient rules); E. Donald Elliott, The Evolutionary Tradition in Jurisprudence, 85 COLUM. L. REV. 38 (1985) (discussing biological approaches to understanding legal evolution); Gillian Hadfield, Bias in the Evolution of Legal Rules, 80 GeO. L.J. 583 (1993); George L. Priest, The Common Law Process and the Selection of Efficient Rules, 6 J. LEGAL STUD. 65 (1977); Mark J. Roe, Chaos and Evolution in Law and Economics, 109 HARV. L. REV. 641 (1996) (addressing path dependence in the evolution of legal rules over time); Paul Rubin, Why is the Common Law Efficient?, 6 J. LEGAL STUD. 51 (1977).

207. See AlAN WATSOn, EvOlution OF LAW (1985) (advancing theory of legal borrowing as a vehicle for legal change); Rudolfo Sacco, Legal Formants: A Dynamic Approach to Comparative Law, 39 AM. J. CoMP. L. 1 (1991); Jonathan B. Wiener, Something Borrowed for Something Blue: Legal Transplants and the Evolution of Global Environmental Law, 27 ECOL. L.Q. 1295 (2001) (discussing horizontal and vertical legal borrowing) (hereinafter Wiener, Something Borrowed); Esin Örücü, Law as Transposition, 51 INT'L \& COMP. L.Q. 205-223 (2002)

208. See Ugo Mattei, Comparative Law And Economics 125-26 (1997) (lamenting the mutual inattention of the theories of legal transplants in comparative law, and efficient evolution in law and economics). Mattei then seeks to bring these two approaches together in a synthesis that explains legal transplants (or their failure to occur) on efficiency criteria. Id. at 126-45. See also Wiener, Something Borrowed, supra note 207, at 1343-62 (analyzing legal borrowing in terms of the positive and normative criteria for efficient evolution of law). 
portfolio of available tools and thereby helps equip the borrower to survive future challenges. ${ }^{209}$ Whereas within-system selection pressures leave surviving those who have survived past environments (potentially yielding local optima in terms of past events, but not overall optima across all future scenarios), inter-system exchange creates hybrid offspring — with a more diversified portfolio of traits - that may be better suited to surviving in the environment yet to come. ${ }^{210}$ Most of the hybrid offspring do not prosper while the environment is stable, but when the environment changes, as it always does, ${ }^{211}$ hybrids can become the basis for successful new species and new legal approaches. Indeed, hybridization is an especially appropriate platform for the evolution of environmental law because the essence of environmental problems is interconnectedness.

Hybridization of law (or species) might look like convergencethe generation of a new approach shared by both systems-but it need not be. Hybridization can imply a complex web of borrowings of particular features applied to different problems, institutions, and levels of government-a hodgepodge of "bricolage" 212 that yields a diffuse and cloudy pattern rather than a tight convergence to a new line. One might observe divergence in one area, convergence in another-many aspects heading in different directions all at once. Or hybridization might give rise to a new version that is quite different from both parental approaches and that appears during the

209. In response to an audience question following his address on within-system legal evolution, Donald Elliott did mention the advantages of a diversified portfolio of legal approaches and, implicitly, of legal borrowing to achieve that diversification, while also seeming to be skeptical of such borrowing. "Because of differences in environments, and also because of the notion that there is a diversity of strategies which are being played in any population, one would not expect the same thing that works in a particular culture to work in another context. This is both because of the environmental differences, and as modern biology teaches us, because there is not a single adaptive strategy.... A distribution of strategies is much more evolutionarily stable. So what one would expect to see, and what one does in fact see, is a variety of different societies playing a variety of different strategies on such things as, for example, security and risk... You can understand these differences in social organizations as different societies playing different strategies, each having different advantages or disadvantages in particular types of environments. So there is absolutely no reason to believe there is going to be a sort of single, universal approach. But it is helpful, I think, in a comparative way, to understand what the different functions are." Elliott, supra note 206, at 619-20.

210. See Grant, supra note 205; Roe, supra note 206 (emphasizing the need to choose legal rules to meet tomorrow's environment, not just yesterday's environment, and the problem of path-dependence and local optima because rules or traits that survive natural selection are the ones that succeeded in yesterday's environment).

211. See Daniel Botkin, Discordant Harmonies (1992); Jonathan B. Wiener, Beyond the Balance of Nature, 7 DUKE ENVTL. L. \& POLICY FORUM 1 (1996).

212. Mark Tushnet, The Possibilities of Comparative Constitutional Law, 108 YALE L.J 1225 (1999). 
both parental approaches and that appears during the transitional process to be divergent from both parental systems.

As a descriptive model for contemporary legal evolution, hybridization seems considerably more realistic than convergence or divergence. Whereas convergence and divergence can both occur with no interaction among the systems, hybridization necessarily involves exchange across systems, which seems obvious in an age of globalization and international trade. Whereas convergence and divergence imply curves heading toward or away from a single point (or line) on a plane, as though legal systems had some determinate and common starting or ending points, hybridization implies an interactive interface between two particle clouds that are continuously exchanging components across one or many planes, thereby reaching and even creating new points on an unfolding multidimensional frontier. Rather than two lines converging or diverging, one can envision two fractals interacting at many junctures as they both evolve. Whereas models of convergence or divergence depict each legal system as a discrete aggregate entity moving in one direction, a model of hybridization corresponds better to a view of legal systems as complex disaggregated multi-nodal networks, with multiple actors pursuing multiple directions at once and interacting across permeable system boundaries in many places at once. ${ }^{213}$

In order to understand U.S. and European environmental policies in this context of complexity, the Duke Center for Environmental Solutions and the European Commission's Group of Policy Advisers have been conducting a project on "The Reality of Precaution." ${ }^{214}$ The project engages participants from both the United States and Europe in order to overcome the problem of ignorance of foreign legal systems. Initial products of this effort include a series of transatlantic dialogue meetings and a jointly-authored research paper. ${ }^{215} \mathrm{~A}$ central finding from this work, as described above in this article, is that the United States and Europe are not diverging or flip-flopping, with Europe becoming "more precautionary" than the United States

213. Hybridization therefore comports better than do convergence or divergence with models of the "disaggregated state" and transnational networks for exchange of ideas. See Robert O. Keohane \& Joseph S. Nye, Transgovernmental Relations and International Organizations, 27 WORLD POL. 39, 43 (1974); Anne-Marie Slaughter, The Real New World Order, FOREIGN AFFAIRS, Sept.-Oct. 1997, at 183, 184.

214. See Duke Center for Environmental Solutions, "The Reality of Precaution," at http://www.env.duke.edu/solutions/precaution_project.html (last visited Mar. 4, 2003) (hereinafter Duke Project).

215. See Wiener \& Rogers, supra note 10. 
across the board. Rather, both the United States and Europe are taking a precautionary approach to the regulation of many risks, but they differ on which risks they choose to worry about and regulate most.

\section{Hybridization in Action}

The foregoing analysis suggests that one cannot characterize the entirety of U.S. and European environmental policies by either convergence or divergence; both are occurring, but differently in different strata of policy development and implementation. A more accurate model to depict current dynamics is hybridization: the exchange of legal concepts across systems. Examples of such borrowing in risk regulation abound. ${ }^{216}$ From the United States, Europe has borrowed approaches to emissions trading, ${ }^{217}$ benefit-cost analysis and executive oversight of the regulatory system, ${ }^{218}$ products liability law, ${ }^{219}$ the pro-

216. A particularly rich archeological history of legal borrowing, recounted to me by Peter Sand (who deserves the credit for this excavation), involves the concept of "sustainable development." As Sand tells the story, the concept originated in 18th century German forestry economics. See HANS CARL VON CARlowitz, Sylvicultura OeCONOMICA (Leipzig 1713) (von Carlowitz was a Saxon lawyer who in turn was inspired by French forest legislation, JeanBaptiste Colbert's "grande ordonnance" of 1669). See book review, at http://www.ejil. org/journal/Vol11/No4/br4.html. It was transplanted from Germany to colonial India in the $19^{\text {th }}$ century by Sir Dietrich Brandis, a German botanist appointed Chief Inspector of Forestry by the British. See Phil McManus, Histories of Forestry: Ideas, Networks and Silences, 5 ENV'T \& HIST 185-208 (1999), at 192-195. For a photo of Brandis, kept at the Forest History Society collection at Duke library, see http://www.lib.duke.edu/forest/Biltmore_Project/Schenck_Mss_ Gallery/Detailed_Pages/FHS292thEAD.htm. Brandis later founded the Forestry School at Oxford and became the mentor of Gifford Pinchot. Pinchot was of course appointed head of the U.S. Forest Service by President Theodore Roosevelt, and authored THE FIGHT FOR CONSERVATION (1910). The transatlantic impact of Brandis is acknowledged in Gifford Pinchot"s autobiographies THE TRAINING OF A FORESTER, (2d ed. London: Lippincott 1937); and especially Breaking New Ground, 56 (1947). See also Char Miller, Gifford Pinchot AND THE MAKING OF MOdERn ENVIRONMENTALISM (2001); and Brian Balogh, Scientific Forestry and the Roots of the Modern American State: Gifford Pinchot's Path to Progressive Reform, 7 ENVTL. HIST. 198-225 (2002). After taking root in North American conservation policy, the sustainability concept was later introduced in the IUCN's 1980 World Conservation Policy by a Canadian forester, David Munro. Another prominent Canadian environmentalist, Maurice Strong, helped to get the concept into the Brundtland Commission's 1987 Report, Our Common Future, and then into the Rio Declaration on Environment and Development in 1992. See Peter H. Sand, A Century of Green Lessons: The Contribution of Nature Conservation Regimes to Global Governance, 1 InTERnATIONAL ENVIRONMENTAL AGREEMENTS: Politics, LAW AND ECONOMICS 58, n.70 (2001).

217. See Golub ed., supra note 160; CEC, Greenhouse Gas, supra note 161.

218. See Commission of the European Communities, Communication on the Precautionary Principle, supra note 21; Commission of the European Communities, Action Plan on Improving Regulation, supra note 59; Commission of the European Communities, Communication on Impact Assessment, supra note 60. The criteria for regulation under the Communication on the 
posed environmental liability directive, ${ }^{220}$ increasingly "federal" oversight of environmental policy, ${ }^{221}$ information disclosure instruments including environmental impact assessment (EIA) and toxics release registries, ${ }^{222}$ and other measures. Meanwhile, from Europe, the United States has borrowed the Dutch method of environmental covenants and related approaches to voluntary negotiated agreements, ${ }^{223}$ and the concept of precaution itself, which originated as vorsorgeprinzip in German law, ${ }^{224}$ and was later relied on in U.S. law. ${ }^{225}$ Additional examples of transatlantic borrowing are undoubtedly underway; for example, Europe may borrow U.S. methods of judicial review and notice and comment rulemaking, ${ }^{226}$ and the United States may borrow from European experience with watershed management ${ }^{227}$ and with subsidiarity. ${ }^{228}$

Hybridization is spurred by several factors. The integrating world economy offers greater opportunities for exchange of ideas and counterpart experiences, while simultaneously putting pressure on na-

PP are actually quite similar to the criteria under U.S. Executive Order 12866, supra note 56.

219. See Mathias Reimann, The End of Comparative Law as an Autonomous Subject, 11 TUL. EuR. \& CIV. L.F. 49, 62 (1996).

220. The Commission has authored a White Paper and proposed legislation on Environmental Liability; the proposed legislation is now pending in the European Parliament. See Commission of the European Communities, Environmental Liability Homepage, updated March 13, 2003, at http://europa.eu.int/comm/environment/liability/index.htm (last visited June 10, 2003).

221. See Eckard Rehbinder \& Richard B. Stewart, Integration Through Law: Europe and the American Federal Experience: Vol. 2, ENVIRONMENTAL PROTECTION POLICY (1985); Breyer \& Heyvaert, supra note 66.

222. See Sand, Information Disclosure, supra note 90; PETER H. SAND, LESSONS LEARNED In Global EnVIronmental Governance 25 (1990); Wiener, Something Borrowed, supra note 207, at 1306-07, n.35 (noting transnational borrowing of EIA requirements); Kerstin Tews et al., The Diffusion of New Environmental Policy Instruments, 42 EuropeAn JOURnal of POLITICAL RESEARCH 569 (2003).

223. See Golub ed. supra note 160; Stewart, New Generation, supra note 178, at 85-86.

224. See Boehmer-Christiansen, supra note 14.

225. See Ethyl Corp.v. EPA, 541 F.2d 1 (D.C. Cir. 1976).

226. See Martin Shapiro, The Giving Reasons Requirement, 1992 U. CHI. LEGAL F. 179; Francesca E. Bignami, The Democratic Deficit in European Community Rulemaking: A Call for Notice and Comment in Comitology, 40 HARV. INT'L L. J. 451 (1999).

227. See Schomburg-Jacoby watershed plan (quoted in P. MENELl \& R. STEWART, ENVIRONMENTAL LAW \& POLICY (1994)) (recommending borrowing of French approach to river basin management).

228. See Vicki Jackson, Ambivalent Resistance and Comparative Constitutionalism: Opening Up the Conversation on 'Proportionality' Rights and Federalism, 1 U. PA. J. CONST. L. 583 (1999) (discussing transatlantic legal borrowing of concepts in federalism); MARK TUSHNET \& ViCKi JACKSON, COMPARATIVE CONSTITUTIONAL LAW (2000) (similar). 
tional regulators to harmonize standards. ${ }^{229}$ Transnational networks of environmental NGOs and policy experts spread legal ideas, ${ }^{230}$ and multinational corporations spread environmental management practices to their foreign operations. ${ }^{231}$ Further, government officials, academics, nongovernmental actors, and businesses are all engaged in a process of learning by doing, in which successful innovations in one place can be observed and imitated (or at least lobbied for) in other places.

Generally speaking, in the design of risk regulatory policies, countries do not follow simple ideologies or cultural trajectories; they do not adopt one overarching paradigm to govern all risks. Across the diverse domains of risk, from food safety (including GM foods and mad cow disease) to global atmospheric risks to violence and terrorism, they select particular policy designs that are stimulated by their contextual circumstances (including perceptions, heuristics and culture) and shaped by their institutional criteria for judging benefits, costs and countervailing risks in each case. ${ }^{232}$

As discussed above, hybridization is not the same as convergence. Hybridization involves exchange, and it is more complex and dynamic than convergence or divergence. And it may be difficult to discern when one is in the midst of its unfolding. Yet it offers both

229. Kagan \& Axelrad eds., supra note 64, at 2-3; Bell, supra note 201, at 161 (describing cross-fertilisation occurring when "confrontation with another system or an international legal order provides the propitious moment for a development in national law"); DYNAMICS OF Regulatory Change: How Globalization AfFects National REgulatory Policies (David Vogel \& Robert A. Kagan eds., Edited Vol. 1, 2002) at http://repositories.cdlib.org/ uciaspubs/editedvolumes/1 (surveying the effects of increasing international trade on several regulatory domains and finding that globalization yields neither a race to the bottom nor a race to the top but rather a variety of convergent and divergent results).

230. See Keohane \& Nye, supra note 213 (emphasizing role of transnational networks and communities of activists and experts); Bell, supra note 201, at 162-64 (describing crossfertilisation via transnational networks of legal scholarship and education); TRANSATLANTIC Governance IN THE Global ECONOMY (Mark A. Pollack \& Gregory C. Shaffer eds. 2001); Nicholas A. Robinson, Introduction to COMPARATIVE ENVIRONMENTAL LAW AND REgUlAtion v, xiii (Nicholas A. Robinson ed. April 1997).

231. See generally Ronie Garcia-Johnson, Exporting Environmentalism (2000); David L. Levy \& Peter Newell, Oceans Apart?, ENV’T MAG., Nov. 2000, at 9-10, 17-18.

232. Similar arguments are made in Wiener, Something Borrowed, supra note 207 (arguing that legal borrowing and evolution are motivated by cost-benefit criteria mediated through the institutional framework in operation each decision); Wyman, supra note 162 (arguing that the United States and Canada have selected market-based incentives where they yield cost savings and not where they don't - rather than adhering to distinct cultures of law); and HOOD ET AL., supra note 95, at 171-86 (concluding that variation across risk regulation regimes within the United Kingdom refutes the broad claims of "risk society" adherents and instead suggests that risk regulation regimes derive from particular contextual factors). 
sides an opportunity to reduce acrimony, to study the complex reality, and to learn from each other. We are both observing and shaping the evolution of our regulatory policies; we can participate in the process of hybridization.

Climate change offers one example. The topic is far too complex to discuss in depth here. But a plausible case can be made that, judged on benefit-cost criteria, the United States should be somewhat more precautionary than its current posture, while insisting on employing robust international emissions trading and fully global participation. ${ }^{233}$ This path would represent a hybrid mixture of the European and American positions to date.

\section{CONCLUSION}

Criticizing an exaggerated claim of U.S. superiority in civil procedure, Herbert Bernstein wrote: "Comparative law is a means to overcome false notions of unmatched greatness and uniqueness. Once this is accomplished, nations can truly learn from each other."234 The same should be said to all participants in the current debate over relative transatlantic precaution. As Oscar Wilde was trying to tell us in The Canterville Ghost, it is a comic error to juxtapose European fear of the dark with American technological hubris. There is much to be gained from comparative analyses, if they can be serious, respectful, and open-minded. Differences among regulatory policies can be the source of insight rather than discord. Our goal should be constructive dialogue and mutual learning.

Claims that United States and European environmental policies are converging or diverging miss the more complex-and more interesting-reality. Viewed across several strata of policy development and implementation, there are areas of divergence (such as the rhetorical framing of precaution, the formality of risk assessment, and the style of legal enforcement) and areas of convergence (such as the substantive criteria for standard setting, the choice of policy instruments, and the hierarchical level of authority). Across the broad array of risks, neither Europe nor the United States can claim to be categorically more precautionary than the other across the board. Several cases, including diesel emissions, mad cow disease, violence, and terrorism, illustrate the simultaneous advocacy of precaution on both sides of the Atlantic.

233. See STEWART \& WIENER, supra note 76.

234. Bernstein, supra note *, at 599. 
The most striking and interesting aspect is the simultaneous convergence/divergence involving precaution and the choice of particular risks to regulate. Viewed across the array of risks, both the United States and Europe are precautionary about many risks (and both resist precaution regarding other risks), but they repeatedly differ as to which risks to worry about and regulate most or earliest. Without denying that broad principles and broad trends can and do matter, it is at this level of the particular risk and particular policy that regulation actually makes a difference and that sharp transatlantic disputes arise. Given the increasing integration of world markets and culture, and the close historical association of the United States and Europe, it is interesting that such diversity persists in the choice of which risks to worry about and regulate. It is this diversity in precautionary particularity, not precautionary principle, that deserves the most attention.

We are in the midst of a dynamic process of legal hybridization, with interactive exchange of legal concepts occurring continuously. These patterns indicate a process of mutual legal borrowing, from which we can learn a great deal, and to which we can contribute. Risk and responses to it are everywhere, but they are typically studied one at a time rather than in a comprehensive approach. Comparative risk regulation can move beyond the simple models of rivalry, convergence, divergence, and races to the top or bottom. These models assume two discrete regulatory actors each with two options - more precaution or less - moving linearly over time. Instead, comparative risk regulation can embrace the more complex model I have tried to sketch here, with the spatial detail of multiple choice nodes in a vast web of interlinked public and private institutions, each with a wider option space of many different policy designs across several policy strata, and with the temporal dynamism of legal evolution through nonlinear hybridization. As I have tried to do here, comparative risk regulation can draw on the political theory of transnational linkages, the social science of comparative policy analysis, the biological theory of hybrid interbreeding, the mathematics of complexity, the decision theories of choice under uncertainty and multi-dimensional consequences, and the legal theories of efficient evolution and evolution through borrowing. Comparative risk regulation can thereby employ interdisciplinary and integrative methods to develop a far more interesting and instructive picture of precaution, of law, and of legal change. 